\title{
Global-scale distributions of marine surface bacterioplankton groups along gradients of salinity, temperature, and chlorophyll: a meta-analysis of fluorescence in situ hybridization studies
}

\author{
Thomas Lefort* ${ }^{*}$ Josep M. Gasol \\ Department of Marine Biology and Oceanography, Institut de Ciències del Mar (CSIC), Barcelona, Catalonia, Spain
}

\begin{abstract}
We used literature data on marine bacterial (sub)group abundances, as determined by fluorescence in situ hybridization, to test whether the ecological variability of the different subgroups was similar to that of the bacterial community as a whole. Patterns of 6 major groups are described (Alpha-, Beta-, Gammaproteobacteria and Bacteroidetes, as well as Rhodobacteraceae and SAR11) and related to environmental variables such as chlorophyll a (chl a) concentration, salinity, and temperature, distinguishing between coastal or open-ocean environments. Coastal ecosystems exhibited higher relative abundances (average \% of DAPI counts) of Bacteroidetes $(23 \%)$, Beta- $(11 \%)$ and Gammaproteobacteria (10\%), and Rhodobacteraceae $(6 \%)$, while significantly higher contributions of Alphaproteobacteria and SAR11 (32\%) were on average enumerated offshore. Multiple regression analyses showed significant explanatory power of chl $a$ and temperature on total and SAR11 absolute abundances (expressed as cells ml ${ }^{-1}$ ), and of chl $a$ and salinity levels on absolute abundances of Betaproteobacteria and Rhodobacteraceae. Other analyses revealed increasing contribution of Gammaproteobacteria for increasing temperatures and high temperature avoidance for Betaproteobacteria. Significantly different log-log regression slopes were found between bacterial group absolute abundances and chl a concentration at a global scale, ranging from $0.13 \pm 0.04$ (SE) for SAR11 to $0.53 \pm 0.08$ for Betaproteobacteria. The different patterns observed for the different groups, in coastal and open-ocean environments, suggest different niche preferences by each group as well as a coherent response to environmental factors.
\end{abstract}

KEY WORDS: Biogeography $\cdot$ FISH $\cdot$ Bacteria $\cdot$ Chlorophyll $a \cdot$ Phytoplankton biomass

\section{INTRODUCTION}

Bacteria do not constitute a uniform pool and their patterns of variability can be studied at different levels, either considering 'bacteria' as a whole, or dividing the community into the main phylogenetic groups that comprise the pool. Evidences of a trophic coupling between phytoplankton and bacteria in aquatic ecosystems were first found empirically by observing a significant correlation between bacteria, taken as a whole, and phytoplankton biomass, as estimated from chlorophyll a (chl a) concentration (Bird \& Kalff 1984, Cole et al. 1988). This coupling between autotrophs and heterotrophs was taken to suggest that bacteria use mainly the dissolved organic matter produced by phytoplankton to support growth through bacterial production (Nagata 2000, Morán et al. 2002). Studies based on the analysis of large data sets have evidenced the generality of such a link. Bacteria and $\mathrm{chl} a$ are generally related with a positive relationship and a log-log slope $<1$ between heterotrophic and autotrophic biomass (Simon et al. 1992, Gasol \& 
Duarte 2000), indicating that bacterial biomass varies proportionally less than chl a. This relationship was shown to differ among habitat types such as the open ocean, which had more heterotrophic biomass per unit autotrophic biomass than coastal ecosystems (Gasol et al. 1997, Gasol \& Duarte 2000). It also varied between freshwater and marine habitats (Simon et al. 1992). In a comparative analysis approach comprising 13973 paired data of bacterial abundance and chl a concentration, Li et al. (2004) showed that the relationship was upper-limited at high productivity levels, indicating a macro-ecological limit to bacterial abundance in highly productive waters.

Molecular techniques based on the detection of $16 \mathrm{~S}$ rDNA sequences have shown that members of a variety of phylogenetic groups compose the bacterial community. Fluorescence in situ hybridization (FISH) allows quantifying the contribution of different bacterial groups to the total bacterial community, independently of the biases associated with PCR amplification (e.g. von Wintzingerode et al. 1997, Amann \& Fuchs 2008). Based on the staining of the bacterial small subunit (16S) rRNA ribosomes after hybridization with specific probes, this technique was initially limited by the difficulty of detecting the small and slow-growing oceanic bacterial cells, but new hybridization protocols have considerably increased the limit of detection (Schönhuber et al. 1997, Pernthaler et al. 2002). For example, different FISH protocols have allowed differentiation of the contribution of different bacterial groups in distinct habitats such as freshwater or marine ecosystems (Glöckner et al. 1999) and also to describe the spatio-temporal dynamics of bacterial community structure in a variety of natural habitats (Alfreider et al. 1996, Llobet-Brossa et al. 1998, Murray et al. 1998, Simon et al. 1999, Kirchman et al. 2005). These studies have shown that the Alphaproteobacteria group dominates in marine coastal waters (e.g. Kirchman et al. 2005), contrasting with Betaproteobacteria found more abundantly in freshwaters (Glöckner et al. 1999, Bouvier \& del Giorgio 2002). The SAR11 cluster, a distinct branch within the Alphaproteobacteria phylum, dominates surface ocean bacterial communities in nutrient-depleted areas such as oligotrophic waters of the Sargasso Sea (Morris et al. 2002), but also in coastal Mediterranean waters in spring and summer (Alonso-Sáez \& Gasol 2007). The Rhodobacteraceae group of marine Alphaproteobacteria appears in most marine environments, and is generally more abundant in bacterial communities associated with marine algae (Buchan et al. 2005). The Bacteroidetes constitutes one of the major picoplankton groups and appears to dominate in a va- riety of ecosystems such as cold waters (Simon et al. 1999, Abell \& Bowman 2005) and coastal waters (Eilers et al. 2001, O'Sullivan et al. 2004, Alonso-Sáez \& Gasol 2007) where it can account for as much as half of all bacterial cells counted by FISH (Cottrell \& Kirchman 2000), and in some offshore conditions (Simon et al. 1999, Abell \& Bowman 2005, Schattenhofer et al. 2009), often associated with phytoplankton blooms (Simon et al. 1999).

The geographical distribution of the different bacterial groups does not vary at random but is controlled by several environmental factors. Alonso-Sáez \& Gasol (2007) showed that the relative contribution of Bacteroidetes, Rhodobacteraceae, and Gammaproteobacteria increased in more productive waters of the subtropical North East Atlantic Ocean. Baltar et al. (2007) reported concomitant decreases of bacterial group relative abundance and pronounced changes in bacterial community structure along a transect in the North Atlantic from coastal to offshore waters. Seasonal studies of bacterial assemblage structure in some habitats such as the NW Mediterranean coastal waters (Alonso-Sáez \& Gasol 2007), the English Channel (Mary et al. 2006), or the California coast (Fuhrman et al. 2006) indicate that a variety of environmental parameters participate in the spatio-temporal variability observed in bacterial community structure. For instance, patterns of bacterial group distribution have been observed along a gradient of salinity, with a shift in the dominance of Betaproteobacteria in ecosystems influenced by freshwater inputs to a predominance of Alphaproteobacteria in more open-water conditions (Bouvier \& del Giorgio 2002, Kirchman et al. 2005). New high-throughput methodologies for determining bacterial diversity show these processes driving bacterial biogeography to be prevalent (e.g. Herlemann et al. 2011)

However, all of these studies describe bacterial group distribution and their controlling factors in particular habitats, and only few have analyzed community structure at a larger, more global scale. Using both quantitative PCR and FISH, Selje et al. (2004) reported distinct patterns in the large-scale distribution of SAR11 and various Roseobacter clades. At the global ocean scale, Wietz et al. (2010) used catalyzed reporter deposition (CARD)-FISH to analyze latitudinal and biome-related patterns in bacterial group distribution, showing significantly differing bacterial communities in cold and warm oceans. Little is still known about the macro-ecological patterns of distribution of the different bacterial groups, but we already have a reasonable number of studies and a relatively large data set about bacterial subgroup concentrations that 
allow for a general macro-ecological study. Thus, we set out to statistically explore this database to investigate whether well-constrained relationships at the phylogenetic group level exist between bacterial abundance and ecological factors and are similar, or different, from those existing at the bulk community level. For this endeavor, we collected most published data and describe how the different bacterial subgroup abundances vary with chl a concentration, temperature, and salinity. We tested the null hypotheses that the bacterial group abundances exhibit the same patterns along gradients of chl $a$, temperature, and salinity in coastal and open-ocean ecosystems as those of the bacterial community as a whole. Additionally, we explored the possibility that the patterns are different for the different bacterial subgroups and that the pattern previously identified between the environment and bulk bacterial abundance is an emergent property of the planktonic ecosystem.

\section{MATERIALS AND METHODS}

\section{Data collection}

We electronically searched within the ISI Web of Knowledge (Thomson Reuters) for publications that included the following keywords: marine bacterial community composition, bacterial community structure, fluorescence in situ hybridization (FISH), catalyzed reporter deposition-FISH (CARD-FISH), or marine bacterial assemblages. We completed our selection of studies by going through the literature cited sections of these papers to identify publications that had not been detected in the electronic searches. We found 34 different studies corresponding to 33 published papers to which we added 1 series of unpublished CARD-FISH results of bacterial group abundance in Blanes Bay, NW Mediterranean from 2008 to 2010 (Ruiz-González et al. unpubl.).

All these studies (Table 1; see Appendix 1 for sampling sites) presented bacterial subgroup abundances or at least total bacterial abundance and \% contribution of each group, in addition to the necessary ancillary data (at least chl $a$, temperature, and salinity when available).

We centered our study on the bacterial groups that have been previously described as major contributors to total bacterial community structure, in particular, Alphaproteobacteria (with a particular focus on SAR11 and Rhodobacteraceae), Gammaproteobacteria, Bacteroidetes, Betaproteobacteria, and total Eubacteria to compare with total bacterial abundance.

\section{FISH and CARD-FISH procedures}

From the 34 studies selected, 16 used basically a 'FISH' protocol, as in Cottrell \& Kirchman (2000, 2003), and 16 used a 'CARD-FISH' protocol as described by Pernthaler et al. (2004) and 2 used both approaches. To target the bacterial groups, the bacterial probes considered in most publications were: ALF968 (5'-GGT AAG GTT CTG CGC GTT-3') for Alphaproteobacteria (Glöckner et al. 1999), GAM42a (5'-GCC TTC CCA CAT CGT TT-3') for Gammaproteobacteria (Manz et al. 1992), and CF319a (5'-TGG TCC GTG TCT CAG TAC-3') for the class Flavobacteria of the phylum Bacteroidetes (Manz et al. 1996), BET42a (5'GCC-TTC-CCA-CTT-CGT-TT-3') for Betaproteobacteria (Manz et al. 1992), and the probe EUB338 I-III (5'-GCT GCC TCC CGT AGG AGT-3') as a general probe mixture targeting Eubacteria (Amann et al. 1990, Daims et al. 1999). In most studies, a negative control with the EUB antisense probe NON338 (5'ACT CCT ACG GGA GGC AGC-3') (Wallner et al. 1993) was used to determine non-specific binding.

In addition, the relative abundances of the SAR11 and Rhodobacteraceae clusters were also analyzed mostly using the probes SAR11-441R (5'-TAC AGT CAT TTT CTT CCC CGA C-3') (Morris et al. 2002) and Ros537 (5'-CAA CGC TAA CCC CTC C-3') (Eilers et al. 2001). However, other probes were also used to target SAR11, such as SAR11/486 (5'-GGA CCT TCT TAT TCG GGT-3') (Fuchs et al. 2005) and SAR11/542R (5'-TCC GAA CTA CGC TAG GTC-3') (Morris et al. 2002). Probe RSB67 (5'-CGC TCC ACC CGA AGG TAG-3), specific for the Alphaproteobacteria subgroup Rhodobacteraceae was also used in some studies (Zubkov et al. 2001) (see details in Table 1).

\section{Data extraction}

Most data were from the surface ocean layer (except those of the CARIACO basin data set, Table 1). Relative abundances were expressed in terms of \% contribution to total DAPI counts or to total flow cytometric counts, while absolute abundances were expressed in number of cells $\mathrm{ml}^{-1}$. The subgroup concentrations were paired with chl a concentration and the other environmental variables such as temperature $\left({ }^{\circ} \mathrm{C}\right)$ and salinity when information was available. Some data were obtained from histogram graphs and digitized with the use of GraphClick v.3 (Arizona Software).

Considering the break shelf as the limit between coastal and open-ocean ecosystems, 20 of the studies 
Table 1. Data sources used in this study, with the oligonucleotide probes considered as well as the type of fluorescence in situ hybridization (FISH) protocol. CARD: catalyzed reporter deposition

\begin{tabular}{|c|c|c|}
\hline Sampling sites & Probes & Source \\
\hline \multicolumn{3}{|l|}{ CARD-FISH } \\
\hline Atlantic & EUB338 I-III, SAR11-441R, GAM42a, CF319a & Schattenhofer et al. (2009) \\
\hline Canada Arctic shelf & EUB338, ALF968, BET42a, GAM42a, CF319a & Garneau et al. (2006) \\
\hline Coastal North Sea & CF319, Ros537 & Alderkamp et al. (2006) \\
\hline Coastal Western Arctic & $\begin{array}{l}\text { EUB338-II-III, ALF968, BETA42a, CF319, SAR11-441R, } \\
\text { ROS537, GAM42a }\end{array}$ & Alonso Sáez et al. (2008) \\
\hline English Channel & $\begin{array}{l}\text { EUB338 I-II-III, ALF968, SAR11-152R, SAR11-542R, } \\
\text { RSB67, GAM42a, CF319a }\end{array}$ & Mary et al. (2006) \\
\hline Global survey & EUB338, ALF968, BET42a, GAM42a, CF319 & Wietz et al. (2010) \\
\hline $\begin{array}{l}\text { NW Africa upwelling to Canary } \\
\text { Coastal Transition zone }\end{array}$ & EUBI-II-III, SAR11-441R, CF319a, ROS537, GAM42a & Baltar et al. (2007) \\
\hline NW Black Sea & $\begin{array}{l}\text { EUB338, ALF968, BET42a, GAM42a, ROS537 } \\
\text { AND ROS1029 }\end{array}$ & Stoica \& Herndl (2007) \\
\hline $\begin{array}{l}\text { NW Mediterranean } \\
\text { coastal waters }\end{array}$ & EUB338, ALF968, BET42a, GAM42a, ROS538 & Garcés et al. (2007) \\
\hline $\begin{array}{l}\text { NW Mediterranean } \\
\text { coastal waters (Blanes Bay) }\end{array}$ & $\begin{array}{l}\text { EUB338, ALF968, BET42a, GAM42a, } \\
\text { SAR11-441R, ROS537 }\end{array}$ & Alonso Sáez \& Gasol (2007) \\
\hline $\begin{array}{l}\text { NW Mediterranean } \\
\text { coastal waters (Blanes Bay) }\end{array}$ & $\begin{array}{l}\text { EUB338, ALF968, BET42a, GAM42a, SAR11-441R, } \\
\text { ROS537 }\end{array}$ & Alonso Sáez et al. (2006) \\
\hline $\begin{array}{l}\text { NW Mediterranean } \\
\text { coastal waters (Blanes Bay) }\end{array}$ & $\begin{array}{l}\text { EUB338-II-III, ALF968, BETA42a, CF319, SAR11-441R, } \\
\text { ROS537, GAM42a }\end{array}$ & $\begin{array}{l}\text { C. Ruiz-González et al. } \\
\text { (unpubl.) }\end{array}$ \\
\hline Ría de Vigo, Atlantic & $\begin{array}{l}\text { EUB338, ALF968, BET42a, GAM42a, CF319a, } \\
\text { SAR11-441R, ROS537 }\end{array}$ & Teira et al. (2008) \\
\hline Scotia Sea, Antarctica & $\begin{array}{l}\text { EUB338, ALF968, SAR11-486, SAR11-542R, ROS537, } \\
\text { GAM42a, CF319a }\end{array}$ & Topping et al. (2006) \\
\hline Southwestern Atlantic & $\begin{array}{l}\text { EUBI-III, ALF968, GAM42a. BET42a, CF319, } \\
\text { SAR11-441 }\end{array}$ & Piccini et al. (2006) \\
\hline South Pacific Ocean & EUB338, ALF968, GAM42a, CF319A & Obernosterer et al. (2008) \\
\hline \multicolumn{3}{|l|}{ FISH/CARD-FISH } \\
\hline Cariaco system & EUB338, ALF968, BET42a, GAM42a, CF319 & Lin et al. (2008) \\
\hline $\begin{array}{l}\text { Eastern sub-basin of the } \\
\text { Cariaco system and Black Sea }\end{array}$ & EUB338, ALF968, BET42a, GAM42a, CF319 & Lin et al. (2006) \\
\hline \multicolumn{3}{|l|}{ FISH } \\
\hline BATS, Sargasso Sea & SAR11, CF319, ROS537 & Carlson et al. $(2009)^{*}$ \\
\hline California coast & $\begin{array}{l}\text { EUB338, ALF968, BET42a, GAM42a, CF319a, } \\
\text { SAR11-A1 }\end{array}$ & Cottrell \& Kirchman (2000) \\
\hline Canadian archipelago & EUB338, CF319 & Wells \& Deming (2003) \\
\hline Delaware estuary & EUB338, ALF968, BET42a, GAM42a, CF319a & Kirchman et al. (2003) \\
\hline Delaware estuary & EUB338, ALF968, ROS537, BET42, GAM42a, CF319 & Kirchman et al. (2005) \\
\hline Delaware estuary & EUB338, ALF968, BET42a, GAM42a, CF319 & Yokokawa et al. (2004) \\
\hline $\begin{array}{l}\text { Delaware estuary and } \\
\text { Chesapeake Bay }\end{array}$ & EUB338, ALF968, BET42a, GAM42a, CF319 & Kirchman \& Castle (2004) \\
\hline $\begin{array}{l}\text { Eastern sub-basin of the } \\
\text { Cariaco system }\end{array}$ & EUB338, ALF968, BET42a & Lin et al. (2007) \\
\hline $\begin{array}{l}\text { Mid-Atlantic bight and } \\
\text { North Pacific gyre }\end{array}$ & EUB338, ALF968, SAR11, CF319, ROS537 & Cottrell et al. (2006) \\
\hline NE Subarctic Pacific & $\begin{array}{l}\text { EUBI-II-III, ALF968, ALF1B, BETA42a, GAM42a, } \\
\text { CF319a }\end{array}$ & Agawin et al. (2006) \\
\hline Northern Gulf of Mexico & EUB338, ALF968, ROS536, GAM42a, CFB319 & Vila et al. (2004) \\
\hline Northern North Sea & EUB338, ALF968, GAM42a, CF319a, RSB67 & Zubkov et al. (2002) \\
\hline North Pacific coast & EUB338, ALF968, BET42a, GAM42a, CF319 & Yokokawa \& Nagata (2005) \\
\hline $\begin{array}{l}\text { Oregon, Newport (western US), } \\
\text { North Pacific }\end{array}$ & EUB338, ALF968, BET42a, CF319, GAM42a & Longnecker et al. (2006) \\
\hline South China Sea & EUB338, ALF968, BET42a, GAM42a, CF319 & Zhang et al. (2006) \\
\hline Southern Ocean & EUB338, ALF968, BET42a, GAM42a, CF319 & Simon et al. (1999) \\
\hline
\end{tabular}


were considered to be coastal environments (of these 20, 4 studies were clearly river-influenced or estuarine habitats), 8 were open-ocean, and 6 contained both coastal and open-ocean data.

\section{Chl $a$ and environmental parameter measurements}

Chl a concentration ( $\left.\mu \mathrm{g} \mathrm{ml}^{-1}\right)$, defined operationally as the pigment amount detected from particles retained on glass-fiber membranes, by spectrophotometry or by high-performance liquid chromatography, was used as a proxy of ecosystem productivity status (low and high chl a concentration are used as proxies of low and high productivity levels). All chl a concentrations, temperatures, and salinity parameters corresponded with field measurements performed on the day of sampling. For the study by Kirchman \& Castle (2004), chl a concentrations were not directly available but were estimated from the particulate beam attenuation coefficient $\left(C_{\mathrm{p}}\right)$ results following the relationship: chl a $\left(\mu \mathrm{g} \mathrm{l}^{-1}\right)=2.6 C_{\mathrm{p}}-0.014$, as proposed by Behrenfeld \& Boss (2003).

In all selected studies, calibrated multiparametric probes and conductivity-temperature-depth probes were used for measuring temperature and salinity (see the specific references for details, Table 1).

\section{Standardization of FISH and CARD-FISH results}

As explained above, we combined the data obtained with the FISH and the CARD-FISH protocols. It is well known that, in most ecosystems, the CARDFISH protocol produces higher counts, as it is more sensitive than the FISH protocol (e.g. Pernthaler et al. 2002). In order to be able to compare the relative abundances (\% of DAPI) and the absolute cell abundances (calculated from the total DAPI) measured by FISH and CARD-FISH, we conducted a standardization of the relative abundances, assuming that all the FISH and the CARD-FISH estimates came from the same global 'population,' and that both methodologies had sampled enough to obtain a fair representation of the contribution of each group to the global community. For each bacterial group studied, 1-way ANOVA and $t$-tests were conducted on the whole data set to test whether measurements of bacterial group contribution to total bacterial community structure by FISH or CARD-FISH were significantly different. Significant differences were observed for 4 of the 7 groups studied (Alphaproteobacteria, Gammaproteobacteria, Bacteroidetes, and Eubacteria), and their FISH values were corrected accordingly. As an example, for EUB+ cells, we could assume that the average $30 \%$ obtained by FISH and the average $59 \%$ obtained by CARD-FISH are both estimates of the same data 'population.' In that example case, we would bring the $30 \%$ up to $59 \%$ and we would thus multiply all EUB values by the factor 59/30. Concentrations were then computed from the percentages and the total DAPI. When no significant differences were observed between techniques (as was the case for SAR11, Roseobacteria, and Betaproteobacteria), no percentage transformations were conducted. Note that this procedure assumes that the unlabelled cells by FISH that could be labeled by CARD-FISH are distributed equally among all bacterial groups, and that the discrepancy between the 2 methodologies stems from different degrees of activity spread equally within all subgroups. This is likely not the case (large Gammaproteobacteria cells might be better detected by FISH than small SAR11 cells), but we have no way of accounting for these differences.

We ignored specific variations in protocols (although they might be quite relevant, e.g. Bouvier \& del Giorgio 2003). The detection of target cells by FISH is known to vary drastically among the published literature, ranging from $1 \%$ in soil to $100 \%$ of the total bacterial count in enriched culture for Eubacteria across 51 different published reports (Bouvier \& del Giorgio 2003). Not only methodological factors such as the type of fluorochrome or the stringency conditions can significantly influence the performance of FISH, but ecological factors such as ecosystem type (e.g. coastal, open-ocean, freshwater) also explain a large amount of variability in target detection (Bouvier \& del Giorgio 2003).

We also ignored variability in probe coverage, but the known limitations of current probes should be taken into account (e.g. Amann \& Fuchs 2008, DíezVives et al. 2012). Many of the group-specific probes used to target the major taxonomic groups do not have $100 \%$ group coverage, and thus the potential for false identification exists. Whereas false positive identifications are generally caused by the low specificity of the sequence of the probes to bind selectively a particular group (e.g. CF319a was designed to cover the Flavobacteria and Sphingobacteria but is much less efficient at targeting the Bacteroidetes, Amann \& Fuchs 2008), false negative identifications are generally caused by a low cellular ribosome content, or by the inaccessibility of the probe binding site due to the complexity of the structure of the ribosome, or simply by the lack of cell permeabilization during the FISH procedure (Amann \& Fuchs 2008). 


\section{Multivariate analysis}

Both relative (\% contribution to DAPI or total prokaryotes) and absolute abundances (cells $\mathrm{ml}^{-1}$ ) were used in statistical comparisons with chl a concentration, temperature, and salinity. To avoid the differences generated by the scale of the independent variable (chl $a$, temperature, salinity) and to allow for the comparison of the relative impact of each independent variable in multivariate models, we used standardized Beta-coefficients in multiple regression models. All analyses were performed with the JMP (version 5.0.1) statistical software package (SAS Institute). The graphs (see Fig. 1) were created with the software Aabel 2.4 (Gigawiz) with a $7 \times 7$ point moving average.

\section{Linear regression analysis and analysis of covariance}

To compare slopes of relationships between standardized absolute abundances of each bacterial group and the independent variables (e.g. chl a), equations of the regressions are presented as $\log (y)$ $=a+b \log (x)$ with $y=$ cells $\mathrm{ml}^{-1} ; a=$ intercept $; b=$ slope; $x=$ independent variable (e.g. chl $a$ in $\mu \mathrm{g} \mathrm{l}^{-1}$ ). To test for the significance of the slopes and intercepts, Student's t-tests were conducted after applying model I regression analyses. Model I was chosen because of the inequality of error variances between response and explanatory variables (Legendre \& Legendre 1998). To compare linear regressions and test for heterogeneity of slopes, analysis of covariance (ANCOVA) tests were also performed. All tests were conducted with JMP 5.0.1 software (SAS Institute).

\section{Analysis of bacterial group distribution}

The collected data of bacterial group relative abundances and environmental parameters such as chl a concentration, temperature, and salinity were used to estimate the 'preferred' range of environmental parameters for each bacterial group using a quotientrule analysis (QRA, Somarakis et al. 2006). Each environmental variable was divided into regular intervals for which the frequencies of occurrence were calculated and expressed in percentages. The number of intervals in every environmental variable was set to ensure that maximal occurrence per interval did not exceed $20 \%$ of all measurements. For each bacterial group, the average of cell abundance (log transformed) was calculated within each interval of the environmental parameter and then was expressed as a percentage of the group abundance accumulated over the full range of the environmental variable. Then, for every interval, the quotient values were estimated with the equation:

$$
\mathrm{Q}=\frac{\text { bacterial group abundance }(\%)}{\text { frequency of occurence of environmental variable }(\%)}
$$

Quotient values were smoothed using a 3-point running mean and then plotted against environmental factors, reflecting 'preference' (quotient values $>1$ ) or 'avoidance' (quotient values <1) for a specific variable range (interval). A non-parametric Kolmogorov-Smirnov test of goodness of fit (Zar 1999) was used to compare the cumulative frequency distribution of bacterial groups per category of environmental variable against the distribution histograms of that environmental variable. The null hypothesis $\left(H_{0}\right)$ considers that the observed bacterial group distribution should be at random along that environmental variable.

\section{RESULTS}

\section{Environmental parameters}

The data set analyzed was quite representative of the world's oceans: chl a concentrations in coastal environments had an average value of $1.23 \mu \mathrm{g} \mathrm{l}^{-1}$ and ranged from 0.05 to $103.15 \mu \mathrm{g} \mathrm{l}^{-1}(\mathrm{~N}=294)$. A shorter range and lower chl a average, $0.16 \mu g \mathrm{l}^{-1}$, was measured in open-ocean conditions (0.001 to $10.01 \mathrm{\mu g} \mathrm{l}^{-1}$, $\mathrm{N}=197$, Tables $1 \& 2$ ). The large chl a values were measured in the South China Sea and in the NW African upwelling.

Temperature ranged from $-1.3^{\circ} \mathrm{C}$ and $-0.67^{\circ} \mathrm{C}$ to $30.1^{\circ} \mathrm{C}$ and $29.7^{\circ} \mathrm{C}$ in coastal and open-ocean environments, respectively (Tables $1 \& 2$ ). Salinity of coastal waters ranged from 0.08 recorded in the Delaware estuary, USA (Kirchman et al. 2003), to a maximum of 38.7 measured at the Blanes Bay station in the NW Mediterranean (Alonso-Sáez \& Gasol 2007). In openocean waters, a minimum was measured in the Arctic at 20.3 (Garneau et al. 2006) and a maximum in the Sargasso Sea at 36.8 (Carlson et al. 2009) (Tables 1 \& 2).

\section{Bacterial group contribution to bacterial community structure (BCS) across ecosystems}

At the global scale, Alphaproteobacteria and Bacteroidetes were the largest contributors to BCS with 


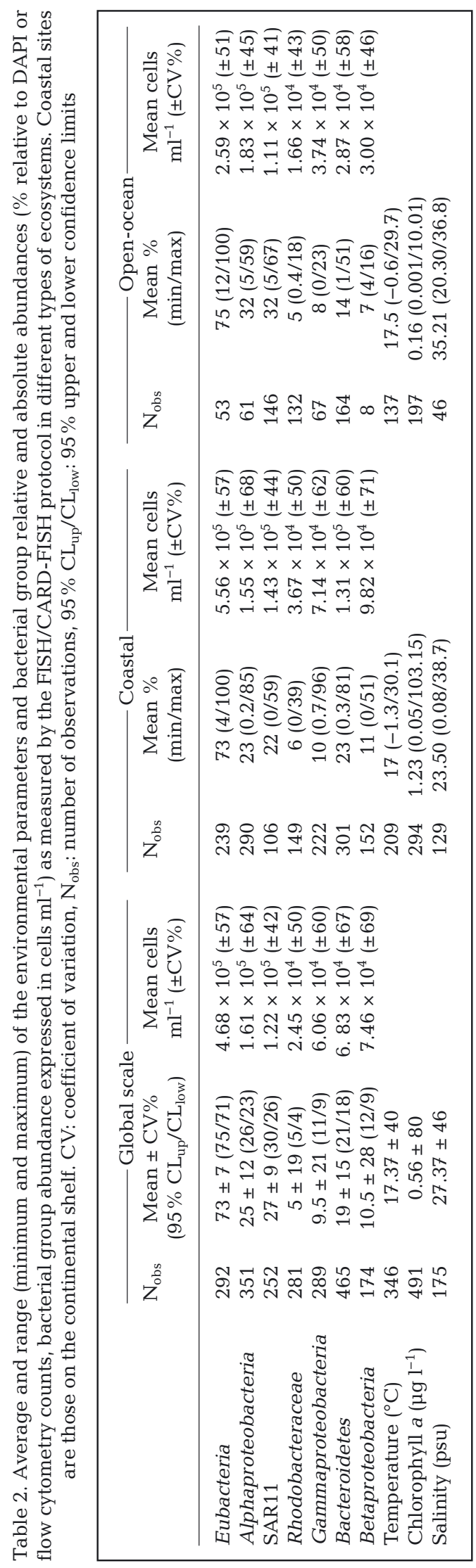

relative abundance averages (expressed as \% of DAPI counts) of $25 \pm 12 \%(\mathrm{CV})$ and $19 \pm 15 \%$, respectively (Table 2). Almost similar contributions were found for Betaproteobacteria and Gammaproteobacteria with respectively $10.5 \pm 28 \%$ and $9.5 \pm 21 \%$.

Alphaproteobacteria relative abundance in coastal ecosystem was on average $23 \%$, with a range of 1 to $85 \%$ (Tables 1 \& 2). In offshore conditions, there was a significantly higher relative contribution of Alphaproteobacteria to BCS (32\%; t-tests, $\mathrm{N}=351$, $\mathrm{p}<0.001$ ) but with a lower range of variability (5 to $59 \%$ ). SAR11 contributed $22 \%$ on average in coastal conditions, ranging from 0 to $59 \%$. Offshore, a similar range of variation (5 to $67 \%$ ) was measured but with a significantly higher average contribution (32\%; t-test, $\mathrm{N}=252, \mathrm{p}<0.001)$. In comparison with Alphaproteobacteria and SAR11, the average relative contribution of Rhodobacteraceae was significantly higher in coastal conditions, with 6.4 and $4.9 \%$, respectively ( $t$-test, $\mathrm{N}=281, \mathrm{p}<0.05$ ). The range was 0 to $39 \%$ in coastal areas and 1 to $18 \%$ in open-ocean environments. The Bacteroidetes relative abundance and range of variation were significantly higher in coastal than in offshore conditions ( $t$-test, $\mathrm{N}=465, \mathrm{p}<0.001$ ). In coastal ecosystems, an average contribution of $23 \%$ (range $<1$ to $81 \%$ ) was found, while offshore, Bacteroidetes contributed an average of $13 \%$ (range $<1$ to $51 \%$ ).

In comparison with open-ocean waters where Gammaproteobacteria contribution to BCS averaged $8 \%$, significantly higher relative contribution of Gammaproteobacteria was observed in coastal environments, averaging $10 \%$ of BCS ( $t$-test, $\mathrm{N}=289, \mathrm{p}<$ $0.001)$ and with a very high range of variability $(<1$ to $96 \%$ ) of the DAPI counts. This unusual strong maximum contribution (>90\% BCS) was found in coastal lagoon waters with high chl a concentration and high temperature in the southwestern coastal Atlantic (Piccini et al. 2006).

As with Bacteroidetes, Gammaproteobacteria, and Rhodobacteraceae, higher relative abundances of Betaproteobacteria were measured at coastal than offshore sampling sites, with averages of respectively 11 and $7 \%$ ( $t$-test, $N=174, \mathrm{p}<0.001)$. Similarly, a higher range of Betaproteobacteria contribution was observed at coastal sites $(<1$ to $51 \%)$ than in offshore environments (4 to $16 \%$; Tables 1 \& 2). Compared with the coast, the number of observations for Betaproteobacteria abundance was very low offshore, mostly observed during coast to offshore transects in the South China Sea and off the Oregon coast (Zhang et al. 2006, Longnecker et al. 2006; Table 1). 


\section{Patterns in BCS across environmental parameters}

We analyzed to what extent the variability measured in the bacterial group contribution to BCS was driven by different environmental parameters such as chl $a$, temperature, and salinity. We first created contour plots to represent the relative contribution to $\mathrm{BCS}$ as a function of chl a concentration and temperature (Fig. 1), and as a function of chl a concentration

A

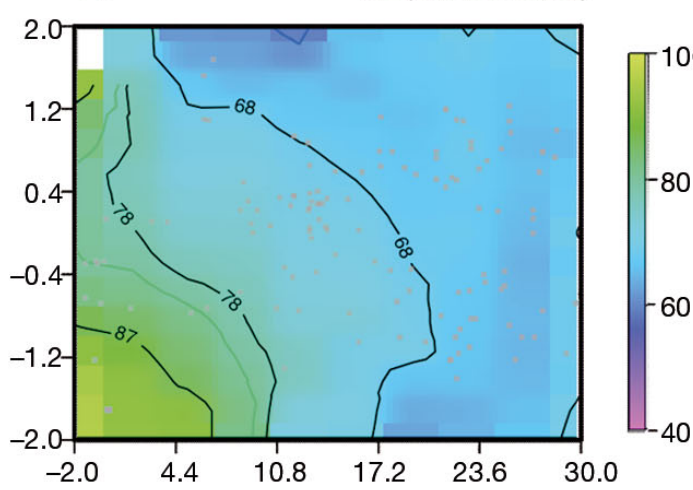

C
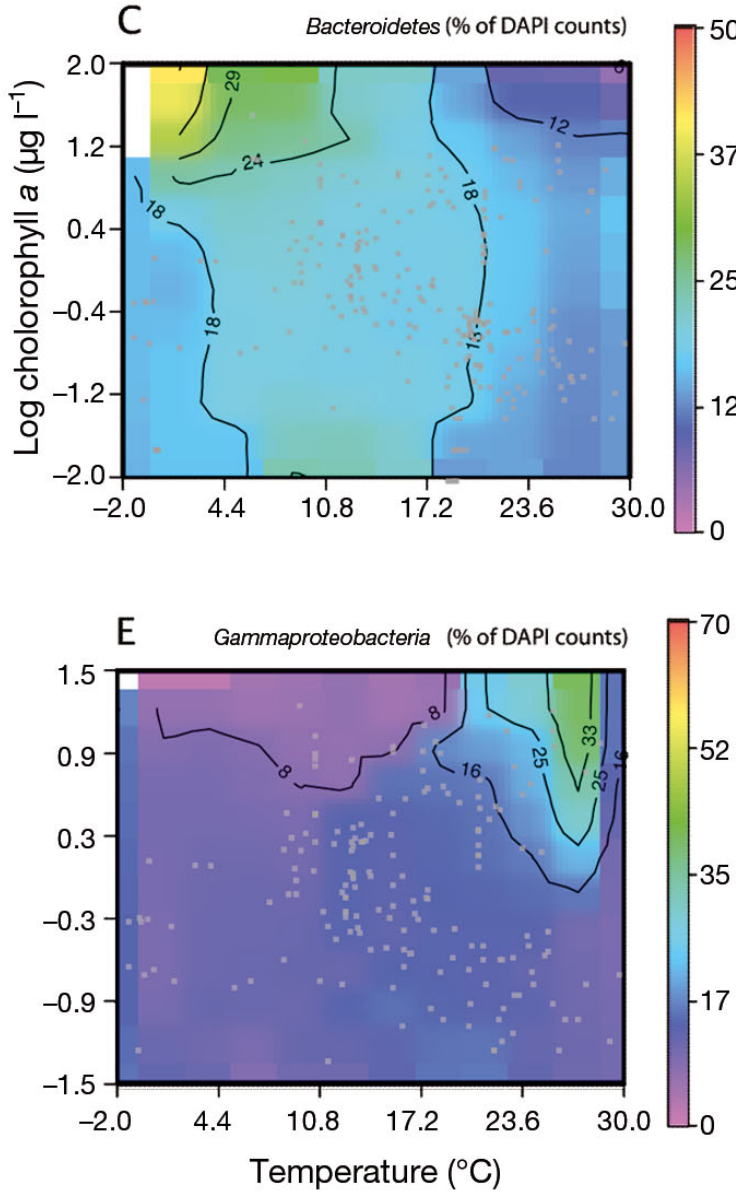

and salinity (Fig. 2). These types of plots are useful to observe general trends, but cannot be used to test for any relationship between the variables. No evident patterns in the relative contribution of Alpha- and Gammaproteobacteria to BCS could be observed across the range of chl a concentrations and temperatures or salinity, the maximum ( $>50 \%$ ) appearing at both low and high temperatures (data not shown). However, strong effects of temperature and chl a
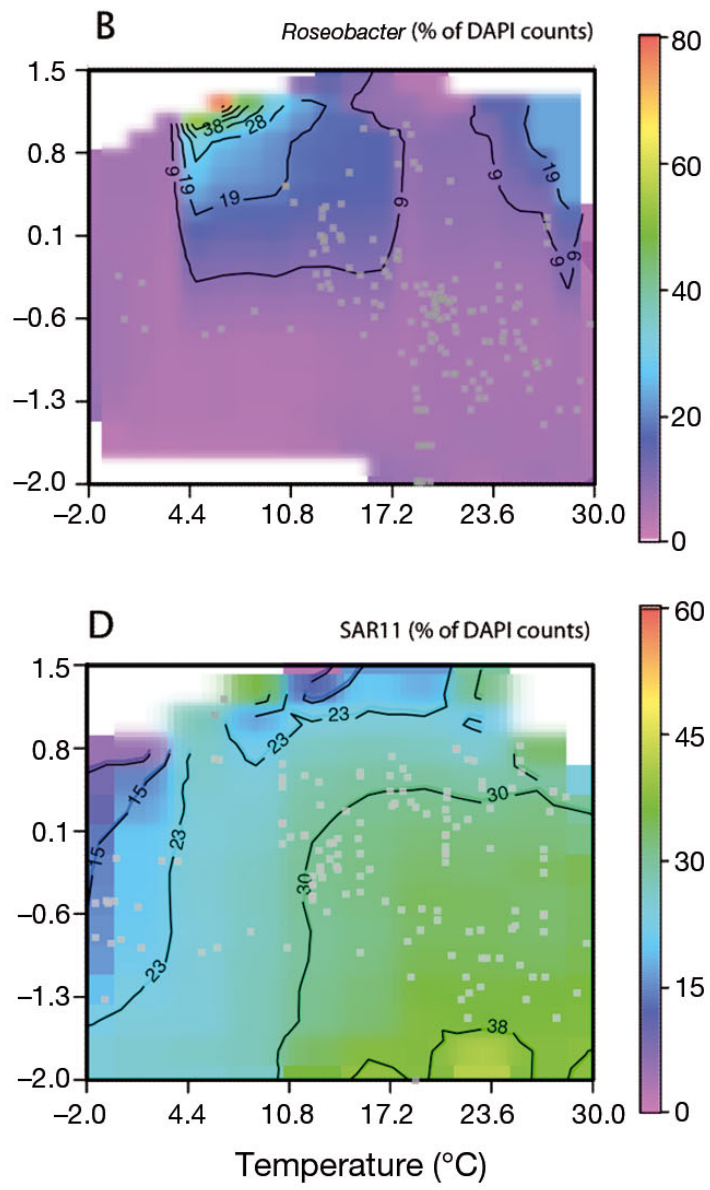

Fig. 1. Contour plots of bacterial group relative abundances (expressed as \% of total bacterial counts) as a function of temperature $\left({ }^{\circ} \mathrm{C}\right)$ and chlorophyll a concentration (log transformed, $\mu \mathrm{g} \mathrm{l}^{-1}$ ). The bacterial groups considered are (A) Eubacteria, (B) Rhodobacteraceae, (C) Bacteroidetes, (D) SAR11, and (E) Gammaproteobacteria. Note that the color scales are different for each plot and that not all data are represented on the contour plots because they are outside the chosen $x$ - and $y$-axis limits 


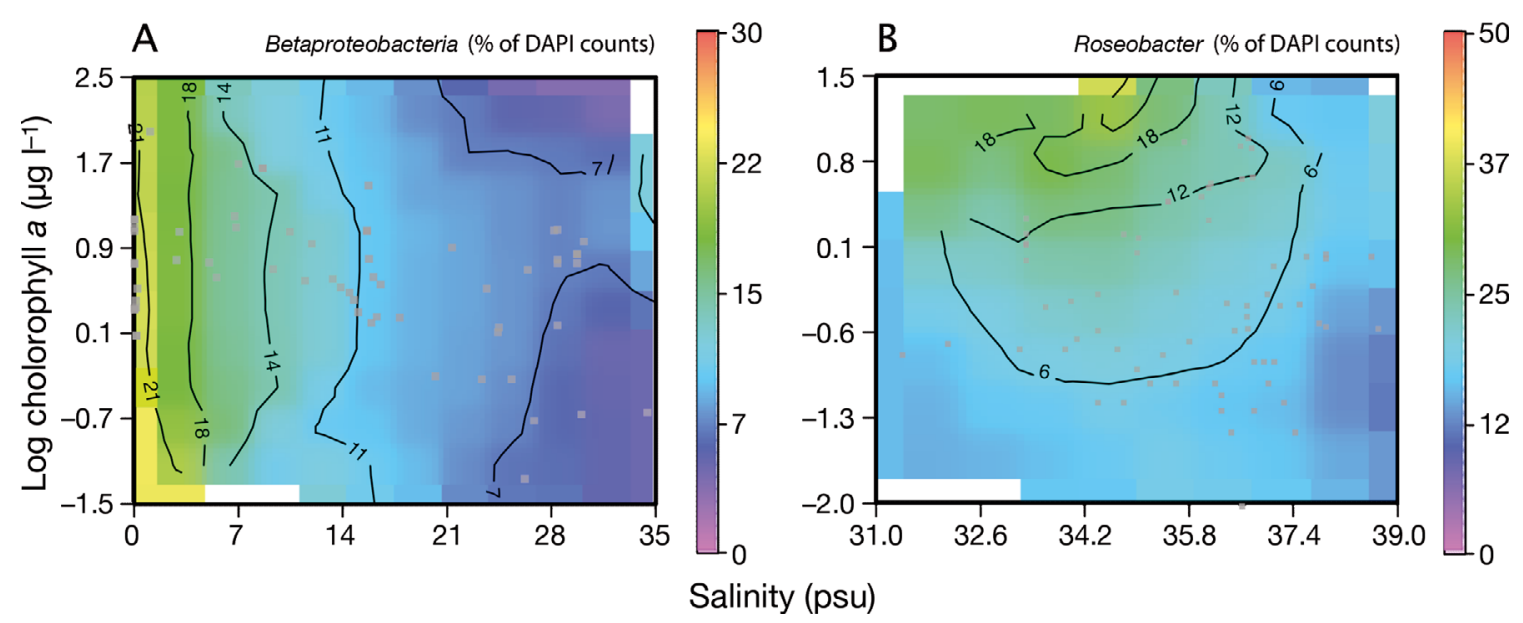

Fig. 2. Contour plots of bacterial group relative abundances (expressed as \% of total bacterial counts) as a function of salinity (psu) and chlorophyll a concentration (log values, $\mu g \mathrm{l}^{-1}$ ). Bacterial groups are (A) Betaproteobacteria and (B) Rhodobacteraceae. Note that the color scales are different for each plot

concentration were seen on eubacterial relative contribution, with its maximum contribution observed at lower chl $a$ and temperature levels (Fig. 1A). Furthermore, the highest Bacteroidetes contribution (>18\%) was observed at high chl a levels but within a large range of temperatures from 2 to $17^{\circ} \mathrm{C}$ (Fig. 1C). Even more pronounced patterns were observed when focusing on the 2 alphaproteobacterial groups: SAR11 and Rhodobacteraceae (Figs. 1B,D \& 2B). While highest SAR11 relative contributions were observed at high temperatures and low chl a concentration (Fig. 1D), Rhodobacteraceae relative abundance increased with increasing levels of chl a concentration (Figs. 1B $\& 2 \mathrm{~B}$ ) and were strongly influenced by salinity (Pearson $t$-test, $\mathrm{N}=70, \mathrm{p}<0.05)$. Similarly, particularly pronounced effects of salinity on Betaproteobacteria relative contribution were obvious (Pearson $t$-tests, $\mathrm{N}=66, \mathrm{p}<0.005$ ), reaching values of $>18 \%$ at salinities $<6$ (Fig. 2A).

The study at narrower phylogenetic levels (compared with the bulk bacterial abundance) showed that the contribution of the different bacterial groups to community structure did not vary uniformly across the intervals of the different environmental variables
(Table 3). While QRA and quotient curve plots showed similar patterns in the preference of Eubacteria, Alphaproteobacteria, and Gammaproteobacteria for increasing chl a levels (even more pronounced for Betaproteobacteria), SAR11, in contrast, exhibited pronounced 'avoidance' and relatively lower contributions to BCS at increasing chl a levels (Fig. 3A, Table 3) with quotient curve values $<1$ at intermediate chl a levels. Gamma- and Alphaproteobacteria, and to a lesser extent Eubacteria, followed similar patterns of preference and avoidance for increasing levels of temperatures (Fig. 3B, Table 3). Not one but several intervals of 'preference' and 'avoidance' were observed for these groups along the gradient of temperature. The contribution of Gammaproteobacteria to $\mathrm{BCS}$ was particularly low from 0 to $7.5^{\circ} \mathrm{C}$ but increased in the temperature intervals 11.9 to $17.4^{\circ} \mathrm{C}$ and 19.6 to $26.2^{\circ} \mathrm{C}$. The opposite pattern was observed in the Betaproteobacteria quotient curve that showed maximum preference for the low temperature intervals 0 to $7.5^{\circ} \mathrm{C}$ and increasing avoidance with increasing temperatures (Fig. 3B, Table 3). Contrasting patterns were also observed with salinity, since increasing preference for high salinity was

Table 3. Results of the Kolmogorov-Smirnov goodness of fit test for the normality assumption of the distribution of the different bacterial group relative abundances. N: number of categories. EUB: Eubacteria. Bold values indicate that the null hypothesis is rejected at a significance level of $\mathrm{p}<0.05$ when the test statistic dmax is greater than the critical value

\begin{tabular}{|c|c|c|c|c|c|c|c|c|c|}
\hline \multirow{2}{*}{$\begin{array}{l}\text { Environmental } \\
\text { variables }\end{array}$} & \multirow[t]{2}{*}{$\mathrm{N}$} & \multicolumn{8}{|c|}{$d \max$} \\
\hline & & $\begin{array}{c}\text { Total } \\
\text { bacteria }\end{array}$ & $\begin{array}{c}\text { Alphaproteo- } \\
\text { bacteria }\end{array}$ & SAR11 & $\begin{array}{c}\text { Rhodo- } \\
\text { bacteraceae }\end{array}$ & $\begin{array}{c}\text { Gammaproteo- } \\
\text { bacteria }\end{array}$ & $\begin{array}{l}\text { Bacteroi- } \\
\text { detes }\end{array}$ & $\begin{array}{c}\text { Betaproteo- } \\
\text { bacteria }\end{array}$ & EUB \\
\hline Log chlorophyll a & 20 & 0.01 & 0.13 & 0.26 & 0.06 & 0.16 & 0.04 & 0.28 & 0.13 \\
\hline Temperature & 20 & 0.02 & 0.20 & 0.18 & 0.16 & 0.21 & 0.05 & 0.23 & 0.15 \\
\hline Salinity & 13 & 0.07 & 0.05 & 0.49 & 0.40 & 0.07 & 0.16 & 0.58 & 0.15 \\
\hline
\end{tabular}



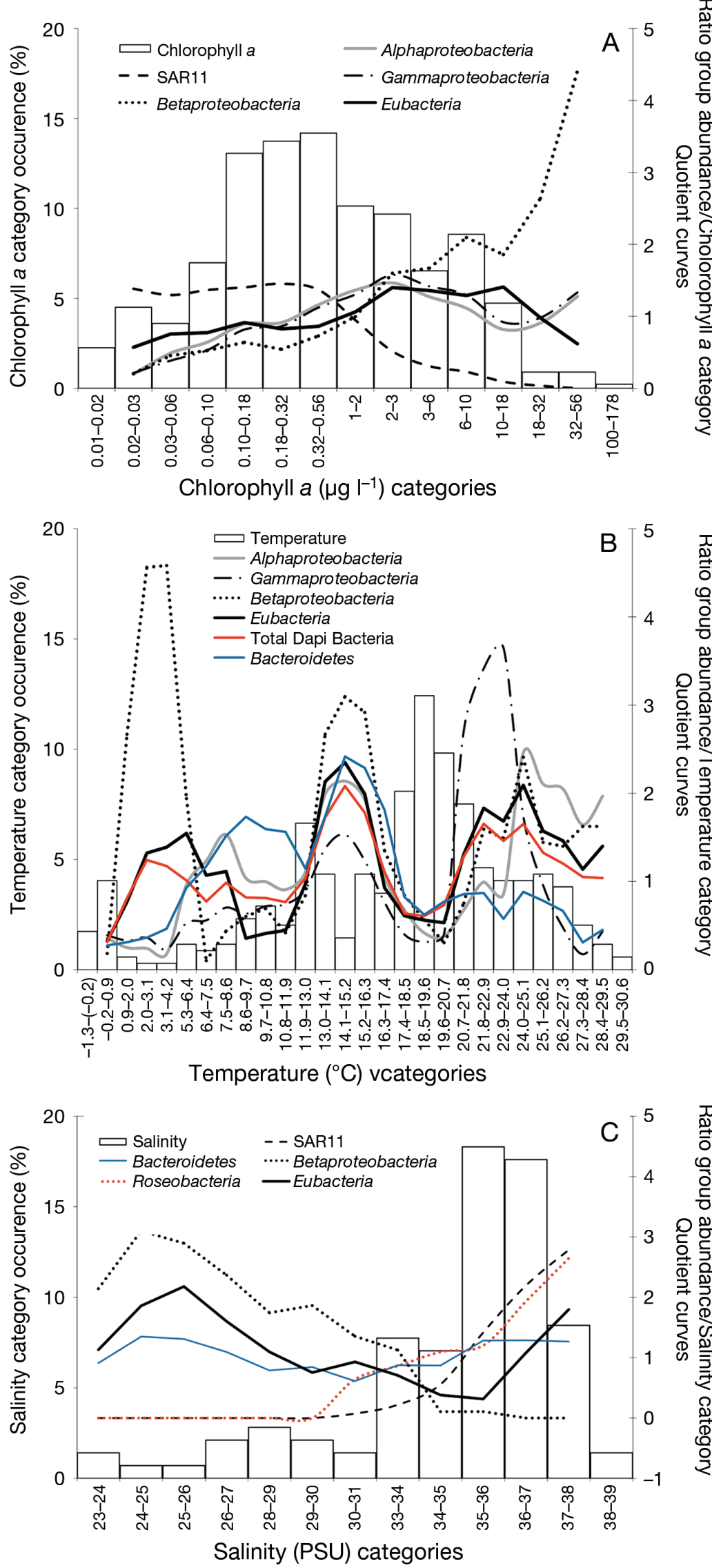

observed for SAR11 and Rhodobacteraceae, in opposition to Betaproteobacteria that showed progressive avoidance with increasing salinity (Fig. 3C, Table 3).

\section{Bacterial group concentrations as a function of chl a}

To investigate the relationships between the different bacterial groups and productivity level (as estimated from chl a concentration), the absolute abundances of each bacterial group were regressed against chl a concentrations (log transformed, Fig. 4). Parameter details of the different equations are presented in Table 4 and follow the form:

standardized log bacterial abundance (cells $\left.\mathrm{ml}^{-1}\right)=$ intercept $( \pm \mathrm{SE})+$ slope $( \pm \mathrm{SE}) \times \log \mathrm{chl} a\left(\mu \mathrm{g} \mathrm{l}^{-1}\right)$

All equations were significant (analysis of variance $\mathrm{p}<0.0001$; Table 4 ). We compared the different relationships and tested for the significance of the homogeneity of slopes, performing an ANCOVA that included interaction of covariates. The homogeneity of slopes assumption was rejected (ANCOVA, $N=1980, p<0.001$ ), indicating that the slopes between bacterial absolute abundance and chl a differed among bacterial groups. Based on individual pairwise comparisons of least squares means in the model using Student's $t$-tests, we observed that the bacterial group abundances increased at different rates with chl a concentration (Fig. 2A).

Fig. 3. Quotient rule analysis showing frequency of occurrence of environmental variables (bars) and quotient curves indicating the ratio of occurrence of bacterial group concentrations relative to the frequency of occurrence of the environmental variables (3-point running means). Environmental variables are (A) chlorophyll a $\left(\mu \mathrm{l}^{-1}\right)$, (B) temperature $\left({ }^{\circ} \mathrm{C}\right),(\mathrm{C})$ Salinity (psu). Bacterial group abundances and chlorophyll a concentrations were log transformed 


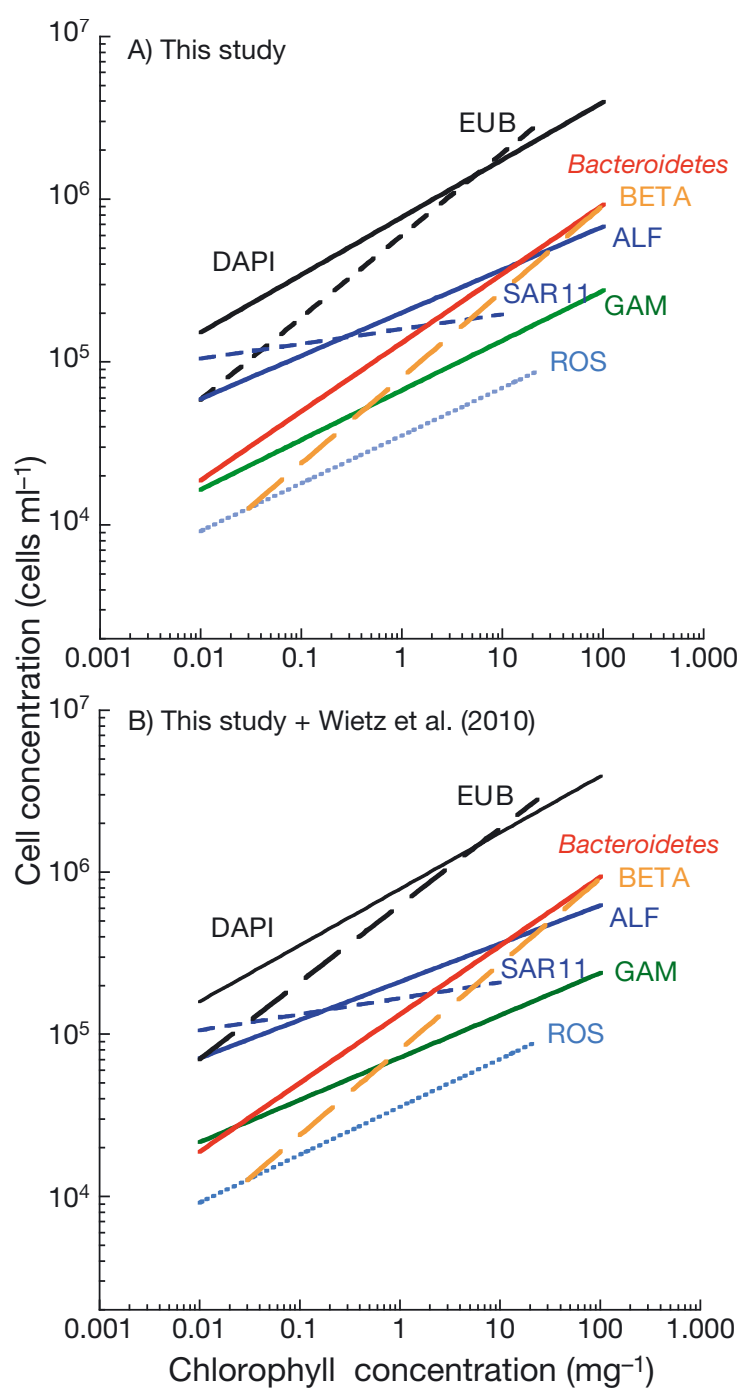

Fig. 4. Relationships between log transformed bacterial subgroup absolute abundances and log chlorophyll a concentration $\left(\mu \mathrm{g} \mathrm{l}^{-1}\right.$ ) (A) with dataset excluding the results from Wietz et al. (2010) and (B) including the results from Wietz et al. (2010). DAPI corresponds to bulk bacterial concentration (cells ml ${ }^{-1}$ ) as counted by DAPI or flow cytometry

The slope of $0.35( \pm 0.02 \mathrm{SE})$ measured at the global scale between bulk bacterial abundance (total DAPI counts) and chl a was significantly different from the different slopes measured at narrower phylogenetic levels (except for Rhodobacteraceae) (Table 4A right panel). The highest slope was found for Betaproteobacteria (Eq. 8A in Table 4A) followed by Bacteroidetes and Eubacteria concentration (Eqs. 7A \& 2A in Table $4 \mathrm{~A}$ ) with respectively $0.53 \pm 0.08,0.49 \pm 0.04$, and $0.48 \pm 0.04$. Since the lowest slope of $0.13 \pm 0.04$ observed for SAR11 was significantly different than the one measured for Alphaproteobacteria at $0.24 \pm$ 0.04 and significantly different intercepts were also measured, the contribution of SAR11 to the Alphaproteobacteria group decreased with increasing chl a levels. No significantly different slopes were found between Alphaproteobacteria, Gammaproteobacteria, and Rhodobacteraceae (Table 4A). However, significantly different intercepts were found between these groups; Alphaproteobacteria and Bacteroidetes dominated BCS at low chl a levels but the slopes indicated that the relative contribution of these groups varies little along the gradient of $\mathrm{chl} a$.

The lowest coefficients of determination $\left(\mathrm{R}^{2}\right)$ were determined for the equations of Alphaproteobacteria, SAR11, and Gammaproteobacteria with respectively $0.10,0.04$, and 0.07, indicating that almost no variance was accounted for by the regression model used, even if significant. The highest $\mathrm{R}^{2}$ values were measured for bulk bacteria and Bacteroidetes, where 47 and $45 \%$ of the variance was respectively explained by chl $a$.

Lastly, individual pairwise comparisons of the least squares means using Student's t-test showed no significant differences between the relationships when including or excluding the dataset by Wietz et al. (2010) ( $t$-tests, $p<0.05$; Fig. 4B, indicating that supplementary data would not significantly change the conclusion).

\section{Coastal versus open-ocean ecosystems}

We investigated how different the relationships between the different bacterial groups and chl a were among coastal or open-ocean ecosystems. The homogeneity of slopes assumption was rejected (ANCOVA, $\mathrm{N}_{\text {coastal }}=1242, \mathrm{~N}_{\text {open }}=738, \mathrm{p}<0.001$ ), indicating that the slopes between bacterial absolute abundance and chl a differed among bacterial groups in both conditions. Comparing the slopes of the relationships among ecosystems using individual pairwise comparisons of least squares means with Student's $t$-test (as previously performed at the global scale), we observed that the bacterial group abundances increased at different rates with chl a concentration (Table 4B,C). Except for the SAR11 and Gammaproteobacteria relationships that were not significant in coastal and open-ocean environments, respectively, all equations were significant in both types of ecosystems (ANOVA, p < 0.0001; Eqs. 4B \& 6C in Table 4).

In coastal conditions, almost no variance was accounted for by the regression equations of SAR11 and Gammaproteobacteria, with $\mathrm{R}^{2}$ values of respectively 0.01 and 0.08 (Table 4B). Higher $\mathrm{R}^{2}$ values were measured for the other equations, ranging from 


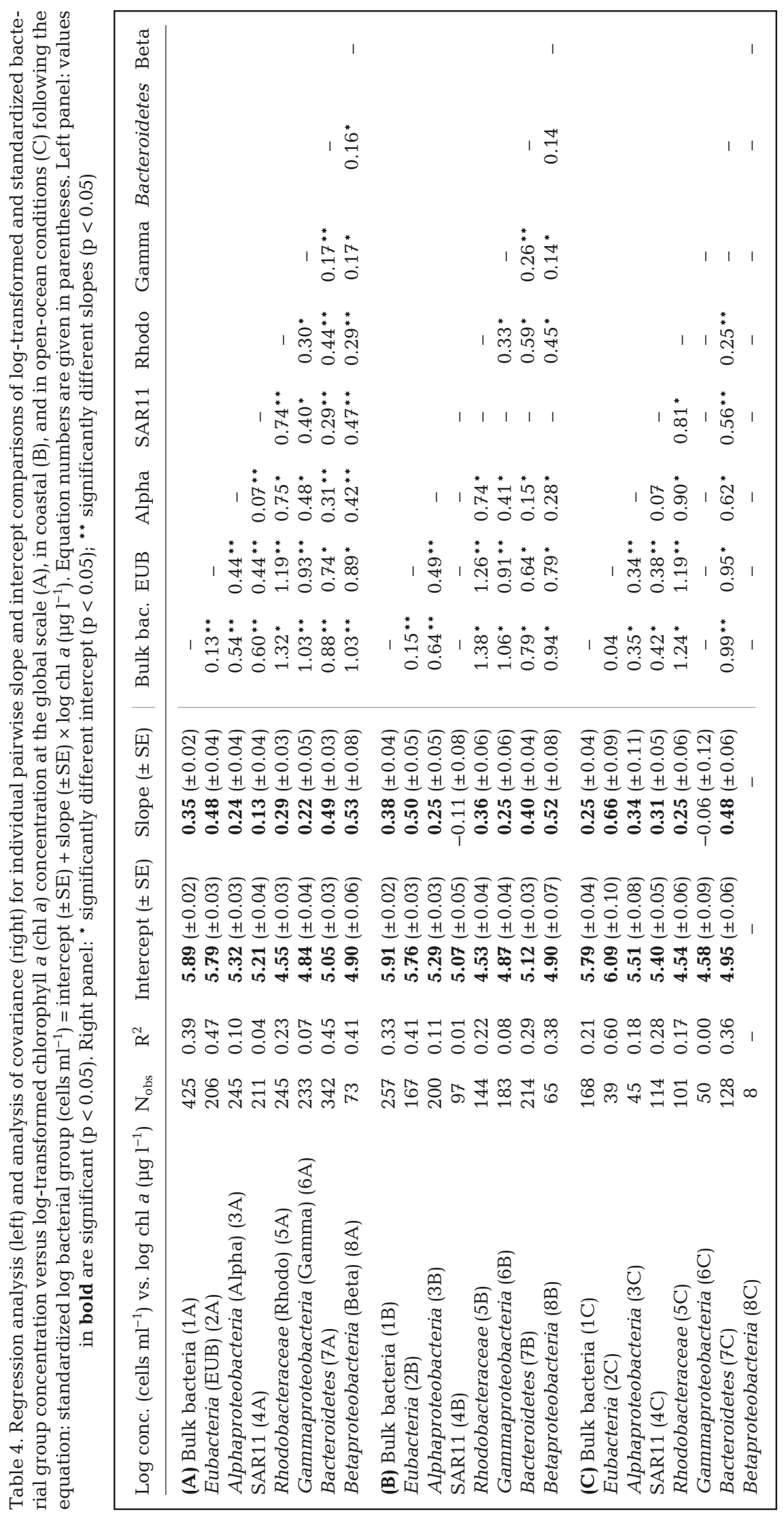

0.22 to 0.41 for Rhodobacteraceae and Eubacteria, respectively, indicating that the regression models were good at explaining these variances. The highest slope was measured for Betaproteobacteria (Eq. 8B in Table 4B) with $0.52 \pm$ 0.08, followed by Eubacteria and Bacteroidetes concentration (Eqs. 2B \& 7B in Table 4B) with respectively $0.50 \pm$ 0.05 and $0.40 \pm 0.04$. Compared with the slope found for SAR11 that was not significantly different from 0 , significant positive slopes were measured for Alphaproteobacteria and Gammaproteobacteria with respectively $0.25 \pm$ 0.05 and $0.25 \pm 0.06$ (Table 4B).

In open-ocean sites, the highest slope was found for Eubacteria (Eq. 2C in Table 4C) followed by Bacteroidetes (Eq. $7 \mathrm{C}$ in Table $4 \mathrm{C}$ ) with respectively $0.66 \pm 0.09$ and $0.48 \pm 0.06$. While no significant slope was found for Gammaproteobacteria with $-0.06 \pm 0.12$ and $\mathrm{R}^{2}$ close to 0 , indicating that no variance was accounted for by the regression, higher $\mathrm{R}^{2}$ and a significantly different slope of $0.31 \pm 0.05$ was measured for SAR11 (Eq. 4C in Table 4C). However, neither significantly different slopes nor different elevations (ordinates) were observed between the SAR11 and Alphaproteobacteria equations (Table $4 \mathrm{C}$ ), indicating that most of the Alphaproteobacteria relationship was driven by the SAR11 contribution to that group. Since significantly different slopes and intercepts were measured between SAR11 and Bacteroidetes, the Bacteroidetes contribution to BCS along the gradient of chl $a$ in open-ocean conditions will tend to increase faster than that of SAR11, and the relative contribution of these 2 groups to community structure will vary accordingly.

\section{Multiple linear regression analysis}

We calculated the standardized beta coefficients in order to compare the effect of different independent variables in multivariate regression models. Bacterial group absolute abundances 


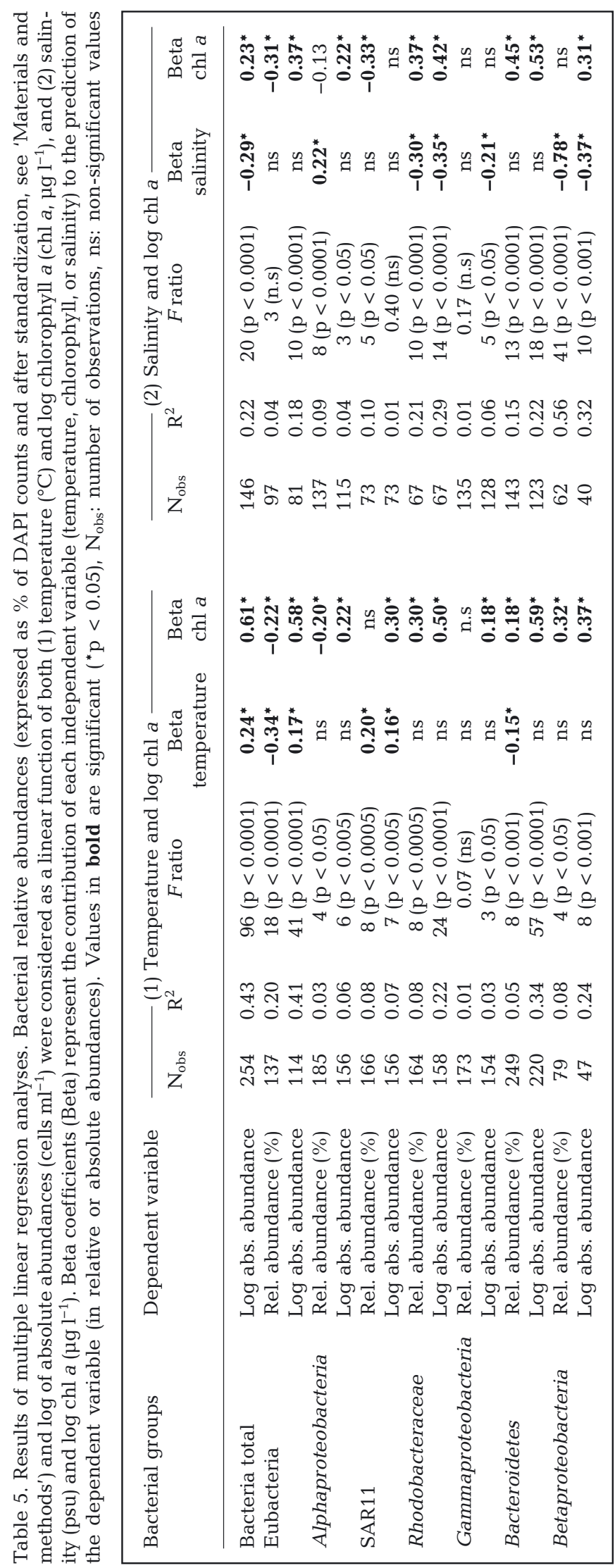

(cells ml ${ }^{-1}$ ) were first expressed as a function of temperature and chl a concentration and second, as a function of salinity and chl a concentration (Table 5). From the beta weights we observed that chl a effects on bacterial absolute abundances were stronger than the temperature effects $(F$-test, $\mathrm{p}<0.05)$. However, total bacterial cell abundance (as counted by DAPI or by flow cytometry), Eubacteria, and SAR11 absolute abundances were significantly controlled by both parameters, indicating that bacterial concentration tended to increase with increasing levels of chl $a$ and with increasing temperatures $(F$-test, $\mathrm{p}<0.05)$. While for total and for eubacterial cell abundances the model using both explanatory variables had coefficients of determination $\left(\mathrm{R}^{2}\right)$ of 0.43 and 0.41 , respectively, indicating that the multiple regression model was successful at fitting the data, the $\mathrm{R}^{2}$ corresponding to the SAR11, Gamma-, and Alphaproteobacteria absolute abundance equations were close to 0 , indicating that very small variance was accounted for by the regressions, in spite of the high statistical significance of the regression equations as measured by the F-ratio.

When bacterial subgroup absolute abundances (cells $\mathrm{ml}^{-1}$ ) were expressed as a function of salinity and chl a concentration (Table 5), we observed both a significant negative effect of salinity and a positive effect of chl a concentration on bulk bacterial concentration, Betaproteobacteria, and Rhodobacteraceae absolute abundances $(F$-test, $\mathrm{p}<0.05)$. For total bacterial abundance and for these 2 groups, the multiple regression equation had $\mathrm{R}^{2}$ of respectively $0.22,0.32$, and 0.29 , indicating that a substantial part of the variability was accounted for by chl $a$ and salinity, both predictor variables being significant $(F-$ test, $\mathrm{p}<0.05)$. High significance of the $F$-ratio $(F$-test, $\mathrm{p}<0.0001)$ showed that the multiple regression equation was a good model for explaining the group absolute abundances.

While we tried regression models with all 3 independent variables (and also including total bacterial abundance as an independent variable), they were not better (i.e. did not have a better F-ratio) than the models with 2 independent variables enumerated above.

\section{DISCUSSION}

Bacterial abundance and biomass measured at the community level have been seen to covary with the trophic status of a variety of ecosystems (Bird \& Kalff 1984, Cole et al. 1988, Gasol \& Duarte 2000). How- 
ever, little is known about the relationship at more specific bacterial phylogenetic levels. Considering the increasing number of studies that have quantified in situ the major bacterial groups composing the bacterial communities, the global scale variability of BCS and its linkage with ecological and environmental parameters should now be identifiable. We intended to establish a phylogeography of the major bacterial groups from in situ estimations by the FISH or CARD-FISH techniques and to define each bacterial group relationship with phytoplankton biomass. For this purpose, we used a statistical approach based on a comparative analysis of 34 different studies reporting both relative and absolute major bacterial group abundance.

\section{Bacterial group biogeography}

Our analysis confirmed the global prevalence of Alphaproteobacteria and the SAR11 clade in both coastal and open-ocean conditions (Morris et al. 2002, Wietz et al. 2010). The particularly pronounced contribution of Bacteroidetes observed here in coastal conditions (whose average relative abundance was similar to the one observed for Alphaproteobacteria; Table 2) contrasted with previous global scale surveys of bacterial community structure done with clone libraries (Pommier et al. 2007) or FISH (Wietz et al. 2010). Several previous studies have described Bacteroidetes as great contributors to BCS in coastal waters and polar regimes, apparently linked to algal blooms and involved in the degradation of polymers such as polysaccharides and proteins (Cottrell \& Kirchman 2000, Eilers et al. 2001), and a certain bias against Bacteroidetes in PCR-based methodologies has also been reported (e.g. Cottrell \& Kirchman 2000, Alonso-Sáez \& Gasol 2007).

Although the range and the average relative abundance of the different groups (expressed in terms of $\%$ of DAPI counts) was significantly higher in coastal rather than in offshore conditions (except for SAR11 and Alphaproteobacteria for which it was the contrary), we showed that the different bacterial groups exhibited different levels of contribution to BCS across different intervals of chl $a$, temperature, and salinity, indicating the presence of biome-related variations in the relative distribution of bacterial groups (Pommier et al. 2007, Wietz et al. 2010). In particular, the preference of Betaproteobacteria for colder waters contrasted with the increasing preference patterns of Gammaproteobacteria for warmer temperatures (Fig. 3). Whether temperature is the only reason explaining the different contribution of some phylogenetic groups occurring at different latitudes cannot be answered; these patterns appeared robust and similar to the previous findings of Wietz et al. (2010), who observed significant differences in the fraction of $B a C^{-}$ teroidetes occurring at low or high latitudes.

The average relative contribution of Alphaproteobacteria, Gammaproteobacteria, Bacteroidetes, and Eubacteria was significantly higher when counted using CARD-FISH than by FISH procedures. Applying a correction factor to these groups in order to cancel out the differences observed between techniques, it could be argued that the methodology used in this metaanalysis for standardizing the data might bias the observed patterns in bacterial group distribution. To discount such a hypothesis, we measured for each of these groups (Alphaproteobacteria, Gammaproteobacteria, Bacteroidetes, and Eubacteria) the ratio between their average contribution as measured by CARD-FISH and their average contribution as measured by FISH, and compared it along a gradient of chlorophyll, temperature, and salinity. Additional 1-way ANOVAs and $t$-tests showed that these ratios (\%CARD-FISH / $\%$ FISH) were constant along the 3 gradients of environmental variables, with no significant differences observed at different levels, indicating that the proportion of FISH to CARD-FISH did not vary with the level of productivity (as measured by chl a), with temperature, or with salinity. We therefore considered that the differences between FISH and CARD-FISH were more likely the result of the methodology and not the result of the environmental variables ( $\mathrm{chl} a$, temperature, salinity) where it was measured.

The patterns observed among the major bacterial groups could also result from the large coverage of these broad bacterial probes, hiding patterns in bacterial community structure at narrower phylogenetic levels. As an example, different SAR11 ecotypes have been shown to vary through time and depth in response to physical and chemical variability (Field et al. 1997, Morris et al. 2005, Carlson et al. 2009). Similarly, the presence of different Flavobacteria clades, such as DE2 in polar biomes and the VISION clades in Arctic provinces, suggests that distinct flavobacterial clades have different niches and could present different life strategies (Gómez-Pereira et al. 2010).

\section{Relationships between bacterial community structure and productivity}

The average relationship between bulk bacterial and autotroph biomass is characterized by a slope $<1$ 
(Gasol \& Duarte 2000). The model I regression slope found in this study averaged $0.35 \pm 0.02$ and was lower than the slope average of $0.46 \pm 0.09$ measured by Li et al. (2004) across a variety of biogeochemical provinces, or the average of $0.47 \pm 0.03$ reported in a comparative analysis of 33 compiled empirical relationships measured earlier from different aquatic ecosystems (Gasol \& Duarte 2000). However, the slopes we measured with Eubacteria (0.48 to 0.66) were larger than the value found with DNA-binding dyes such as DAPI (0.35 to 0.38 ), indicating that the fraction of total cell counts that can be visualized by in situ hybridization increased with the productivity level. The capacity to detect bacteria using FISH has been correlated to RNA content and thus to the single-cell activity state (Karner \& Fuhrman 1997, Tolker-Nielsen et al. 1997) and there is increasing evidence that the hybridization technique preferentially detects cells with a higher level of activity (Oda et al. 2000, Bouvier \& del Giorgio 2003). Since bacterial activity increases with productivity (e.g. Cole et al. 1988), the increasing proportion of cells that could be hybridized with the eubacterial probe might be related to changes in community metabolism as suggested by Bouvier \& del Giorgio $(2002,2003)$.

Here we investigated the coupling between primary producers and bacteria at more detailed phylogenetic levels, focusing on bacterial group absolute abundances as determined by FISH (expressed as cells $\mathrm{ml}^{-1}$ ). Distinct log-log relationships were observed with significantly different regression slopes than the one described between bulk bacterial abundance and chl $a$, ranging from $0.13 \pm 0.04$ to $0.53 \pm$ 0.08 for SAR11 and Betaproteobacteria, respectively, indicating that the different bacterial groups were differently coupled and interrelated to phytoplankton biomass (as estimated from $\mathrm{chl}$ a). The rates at which the different bacterial group abundances increased across the gradient of chlorophyll could indicate different metabolic aptitudes for utilizing the organic matter originating from phytoplankton release processes (e.g. Sarmento \& Gasol 2012) and thus, different contributions to the recycling of organic matter in the ocean. In that sense, the bacterial groups SAR11 and Gammaproteobacteria were the ones with the lowest slopes with chl $a$ and thus with a weaker relationship to phytoplankton, while stronger links were found for Bacteroidetes. However, the strong relationship found between Betaproteobacteria and chl a with a particularly high regression slope of $0.53 \pm 0.08$ was an indirect consequence of high chlorophyll values generally associated with estuarine/bay low-salinity waters. Salinity was the main driver of Betaproteobacteria presence, as measured with the multiple regression beta coefficients that were significant for salinity and not for chl a (Table 5).

It is also possible that the particularly low slope of SAR11 was the consequence of antagonistic effects between bulk abundance and SAR11 relative abundance: SAR11 relative abundance increased in oligotrophic conditions, but the total bacterial number of cells was lower in low-productivity sites, and this effect was reversed in more productive sites. The opposite can also be possible for Betaproteobacteria: with their relative contribution being higher in coastal, low-salinity environments where the bulk abundance is higher, Betaproteobacteria relative abundance and bulk cell number would covary and thus generate a high slope.

\section{BCS-chl a relationships in coastal and open-ocean conditions}

Dividing the dataset according to the type of ecosystem (coastal or offshore), we found different regression slopes between abundance and chl a levels (Table 4B,C). The regression slopes between bulk bacterial biomass and chl a are $<1$ (Gasol \& Duarte 2000, Li et al. 2004), and thus, the bacterial to phytoplankton biomass ratio decreases across a gradient of productivity (Fuhrman et al. 1989, Cho \& Azam 1990, Li et al. 1993, Buck et al. 1996). However, the slope of this ratio has been shown to vary amongst ecosystem type such as offshore, coastal waters, or lakes (Simon et al. 1992, del Giorgio \& Gasol 1995, Gasol et al. 1997). Similarly, evidence of significantly different slopes between bulk bacterial abundance and $\mathrm{chl} a$ concentration in coastal or in offshore conditions has also been reported by both Cho \& Azam (1990), who measured positive regression slopes in eutrophic systems and slopes not statistically different from 0 in oligotrophic systems ( $\mathrm{chl} a<0.5 \mu \mathrm{g} \mathrm{l}^{-1}$ ), and Buck et al. (1996), who also found lower slopes at lower levels of productivity. In our study, relatively lower regression slopes were measured in open-ocean ecosystems than in coastal conditions with $0.25 \pm 0.04$ and $0.38 \pm 0.04$, respectively (Eqs. $1 \mathrm{~B} \& 1 \mathrm{C}$ in Table 4), indicating a lower response of bulk bacterial abundance to increasing phytoplankton biomass in oligotrophic conditions (i.e. Gasol \& Duarte 2000, Gasol et al. 2009). Whilst bacterial community structure was not analyzed in these previous studies, one can consider that such low slopes found at the bulk level in offshore systems may indicate that the bacterial 
groups exhibiting similar weak regression slopes would be those mainly driving the relationship. Indeed, the relatively low slope averages of $0.24 \pm$ 0.04 and $0.22 \pm 0.05$, respectively, found for Alphaproteobacteria and Gammaproteobacteria in comparison with their high contribution to BCS corroborate previous findings by several authors, among them e.g. Baltar et al. (2007), who showed SAR11 (one of the principal contributors to Alphaproteobacteria) as the main component responsible for the variability in bulk prokaryotic abundance along a transect from surface coastal waters to offshore waters of the Canary coastal transition zone.

Contrary to the generalist paradigm that would claim that all bacterial groups use the algal-derived dissolved organic carbon (DOC) in an indiscriminate way (Sarmento \& Gasol 2012 and references therein), evidences of co-occurring shifts in both bacterial and phytoplankton community structures (van Hannen et al. 1999, Pinhassi et al. 2004, Grossart et al. 2005) have stimulated the 'specialist' paradigm, in which bacterial groups are specifically linked to specific phytoplankton groups through the differences in the quality of the excreted dissolved organic matter (Sarmento \& Gasol 2012). In agreement with the relatively high slopes found in the present study between Bacteroidetes and productivity, several studies have not only identified Flavobacteria (belonging to the phylum Bacteroidetes) in the algal phycosphere (RooneyVarga et al. 2005, Sapp et al. 2007) but also reported its association to dinoflagellates (Hold et al. 2001) or diatom blooms either by means of molecular fingerprinting techniques (Riemann et al. 2000), or by determining the number of active Bacteroidetes cells by microautoradiography-FISH (Sarmento \& Gasol 2012). Moreover, evidence of concomitant shifts in bacterial metabolism and community structure during a dinoflagellate bloom off the southern California coast was reported by Fandino et al. (2001). Similarly, using bromodeoxyuridine immunocytochemistry associated with the FISH technique (BIC-FISH), Tada et al. (2011) observed that Betaproteobacteria were strongly correlated with the organic matter supply originating from algae during phytoplankton blooms in the western North Pacific Ocean.

Even though associations of Alphaproteobacteria and Gammaproteobacteria with microalgae have been reported in different studies (Hold et al. 2001, Grossart et al. 2005, Garcés et al. 2007), we measured only weak relationships, as indicated by low $\mathrm{R}$ values (Table 4) with low slopes across the gradient of chl a at the global scale for SAR11 and Gammaproteobacteria with slopes of $0.13 \pm 0.04$ and $0.22 \pm 0.05$, respectively. However, these relationships changed when the type of ecosystem was taken into account. A significantly higher slope of $0.31 \pm 0.05$ was measured for SAR11 in open-ocean conditions, while a significantly higher value was measured for Gammaproteobacteria in coastal conditions, indicating specific links between the different bacterial groups and phytoplankton among each type of ecosystem. SAR11 has been shown by FISH to occur abundantly as freeliving cells in surface oceans (Morris et al. 2002). Evidence of proteorhodopsin gene expression in the strain Pelagibacter ubique (Giovannoni \& Stingl 2005) suggests that SAR11 could produce additional energy by using a light-driven proteorhodopsin proton pump, that may not only confer a growth rate advantage in nutrient-depleted conditions (Giovannoni \& Stingl 2005), but might also loosen the relationships with phytoplankton, as suggested by the particularly low slope measured in our study. Note that a relatively low slope of $0.24 \pm 0.04$ also measured for the whole Alphaproteobacteria group suggests that the Alphaproteobacteria relationship was mostly driven by the high contribution of SAR11 within the Alphaproteobacteria group. This would in turn support the idea proposed by Yokokawa \& Nagata (2005) that particular ecological traits (DOC uptake, bacterial production and growth, grazing rates) can be detected using broad phylogenetic probes, when an ecological trait of a broad group largely reflects the trait of the dominant subgroup in the community. Low coupling between SAR11 and chl a might also indicate the use by this dominant bacterial group in oceanic waters of non-contemporaneous primary production, something that has been suggested to occur for the bulk community across the central Atlantic gyre (Gasol et al. 2009).

On the other hand, a less positive or even zero slope in the relationship between bacterial biomass and the resource gradient can also indicate strong mortality and top-down control on bacteria (Pace \& Cole 1994). Li et al. (2004) found a macro-ecological relationship between bulk bacterial abundance and $\mathrm{chl} a$ and observed non-linearity, from a positive relationship at low levels of productivity to a negative one at high levels of productivity. This shift was thought to represent a transition from bottom-up to top-down control of bacteria by grazing or viruses ( $\mathrm{Li}$ et al. 2004). However, it may also be related to the differences in bacterial community structure as exemplified by the different bacterial regression slopes that we have encountered across the different productivity levels. Indeed, evidence for different patterns in the control of bacterial community com- 
positions linked to differential growth and mortality grazing rates among the major bacterial groups was revealed e.g. by Yokokawa \& Nagata (2005) in western North Pacific coastal waters and by Ferrera et al. (2011) in Blanes Bay, who measured lower growth rates of the more abundant groups such as Alphaproteobacteria, relative to less abundant but fastergrowing Bacteroidetes and Gammaproteobacteria. Ferrera et al. (2011) experimentally showed that even though SAR11 was the most abundant bacterial group, it was also the one with the slowest growth. This links to our findings of weak relationships between Alphaproteobacteria and SAR11 abundance with chl $a$ in coastal ecosystems in comparison to their importance in terms of contribution to BCS.

In conclusion, our results indicate that bacterial community structure is not random but that the contribution of the different groups varies at different rates with a gradient of environmental parameters. Our results point out that the relationships between bacterial group abundance and phytoplankton biomass are a function of the phylogenetic level at which the bacterial community is studied, and also a function of the type of ecosystems in which the relationship is analyzed. Finally, since the explanatory variables identified can be detected from space and modeled with relative ease (e.g. Yoder et al. 2010), our analysis can be used to model global climatologies of the abundances of the different bacterial groups and of BCS.

Acknowledgements. This work was supported by the EUfunded projects METAOCEANS (MEST-CT-2005-019678), and the Spanish MCINN projects STORM (CTM200909352/MAR) and HotMix (CTM2011-30010/MAR). We particularly thank C. Ruiz-González for the unpublished data from Blanes Bay, as well as H. Sarmento for help with statistical analyses.

\section{LITERATURE CITED}

Abell GCJ, Bowman JP (2005) Ecological and biogeographic relationships of class Flavobacteria in the Southern Ocean. FEMS Microbiol Ecol 51:265-277

> Agawin NSR, Hale MS, Rivkin RB, Matthews P, Li WKW (2006) Microbial response to a mesoscale iron enrichment in the NE Subarctic Pacific: bacterial community composition. Deep-Sea Res II 53:2248-2267

> Alderkamp AC, Sintes E, Herndl GJ (2006) Abundance and activity of major groups of prokaryotic plankton in the coastal North Sea during spring and summer. Aquat Microb Ecol 45:237-246

> Alfreider A, Pernthaler J, Amann R, Sattler B, Glöckner FO, Wille A, Psenner R (1996) Community analysis of the bacterial assemblages in the winter cover and pelagic layers of a high mountain lake by in situ hybridization. Appl Environ Microbiol 62:2138-2144

Alonso-Sáez L, Gasol JM (2007) Seasonal variations in the contributions of different bacterial groups to the uptake of low-molecular-weight compounds in northwestern Mediterranean coastal waters. Appl Environ Microbiol 73:3528-3535

Alonso-Sáez L, Gasol JM, Lefort T, Hofer J, Sommaruga R (2006) Effect of natural sunlight on bacterial activity and differential sensitivity of natural bacterioplankton groups in Northwestern Mediterranean coastal waters. Appl Environ Microbiol 72:5806-5813

Alonso-Sáez L, Sánchez O, Gasol JM, Balagué V, PedrósAlio C (2008) Winter-to-summer changes in the composition and single-cell activity of near surface Arctic prokaryotes. Environ Microbiol 10:2444-2454

Amann R, Fuchs M (2008) Single-cell identification in microbial communities by improved fluorescence in situ hybridization techniques. Nat Rev Microbiol 6:339-348

> Amann RI, Binder BJ, Olson RJ, Chisholm SW, Devereux R, Stahl DA (1990) Combination of 16S ribosomal-RNA-targeted oligonucleotide probes with flow cytometry for analyzing mixed microbial populations. Appl Environ Microbiol 56:1919-1925

- Baltar F, Arístegui J, Gasol JM, Hernández-León S, Herndl GJ (2007) Strong coast-ocean and surface-depth gradients in prokaryotic assemblage structure and activity in a coastal transition zone region. Aquat Microb Ecol 50: 63-74

Behrenfeld M, Boss E (2003) The beam attenuation to chlorophyll ratio: an optical index of phytoplankton physiology in the surface ocean? Deep-Sea Res I 50: 1537-1549

Bird DF, Kalff J (1984) Empirical relationships between bacterial abundance and chlorophyll concentration in fresh and marine waters. Can J Fish Aquat Sci 41:1015-1023

$>$ Bouvier TC, del Giorgio PA (2002) Compositional changes in free-living bacterial communities along a salinity gradient in two temperate estuaries. Limnol Oceanogr 47: 453-470

Bouvier TC, del Giorgio PA (2003) Factors influencing the detection of bacterial cells using fluorescence in situ hybridization (FISH): a quantitative review of published reports. FEMS Microbiol Ecol 44:3-15

> Buchan A, González JM, Moran MA (2005) Overview of the marine Roseobacter lineage. Appl Environ Microbiol 71: 5665-5677

> Buck KR, Chavez FP, Campbell L (1996) Basin-wide distributions of living carbon components and the inverted trophic pyramid of the central gyre of the North Atlantic Ocean, summer 1993. Aquat Microb Ecol 10:283-298

> Carlson CA, Morris R, Parsons R, Treusch AH, Giovannoni SJ, Vergin K (2009) Seasonal dynamics of SAR11 populations in the euphotic and mesopelagic zones of the northwestern Sargasso Sea. ISME J 3:283-295

- Cho BC, Azam F (1990) Biogeochemical significance of bacterial biomass in the ocean's euphotic zone. Mar Ecol Prog Ser 63:253-259

Cole JJ, Findlay S, Pace ML (1988) Bacterial production in fresh and saltwater ecosystems: a cross-system overview. Mar Ecol Prog Ser 43:1-10

Cottrell MT, Kirchman DL (2000) Community composition of marine bacterioplankton determined by $16 \mathrm{~S}$ rRNA gene clone libraries and fluorescence in situ hybridization. Appl Environ Microbiol 66:5116-5122 
Cottrell MT, Kirchman DL (2003) Contribution of major bacterial groups to bacterial biomass production (thymidine and leucine incorporation) in the Delaware estuary. Limnol Oceanogr 48:168-178

> Cottrell MT, Mannino A, Kirchman DL (2006) Aerobic anoxygenic phototrophic bacteria in the Mid-Atlantic Bight and the North Pacific Gyre. Appl Environ Microbiol 72:557-564

> Daims H, Brühl A, Amann R, Schleifer KH, Wagner M (1999) The domain-specific probe EUB338 is insufficient for the detection of all Bacteria: development and evaluation of a more comprehensive probe set. Syst Appl Microbiol 22: 434-444

del Giorgio PA, Gasol JM (1995) Biomass distribution in freshwater plankton communities. Am Nat 146:135-152

Díez-Vives C, Gasol JM, Acinas SG (2012) Evaluation of marine bacteroidetes-specific primers for microbial diversity and dynamics studies. Microb Ecol 64: 1047-1055

> Eilers H, Pernthaler J, Peplies J, Glöckner FO, Gerdts G, Amann R (2001) Isolation of novel pelagic bacteria from the German Bight and their seasonal contributions to surface picoplankton. Appl Environ Microbiol 67:5134-5142

Fandino LB, Riemann L, Steward GF, Long RA, Azam F (2001) Variations in bacterial community structure during a dinoflagellate bloom analyzed by DGGE and $16 \mathrm{~S}$ rDNA sequencing. Aquat Microb Ecol 23:119-130

> Ferrera I, Gasol JM, Sebastián M, Hojerová E, Koblížek M (2011) Comparison of growth rates of aerobic anoxygenic phototrophic bacteria and other bacterioplankton groups in coastal Mediterranean waters. Appl Environ Microbiol 77:7451-7458

> Field KG, Gordon D, Wright T, Rappé M, Urbach E, Vergin K, Giovannoni SJ (1997) Diversity and depth-specific distribution of SAR11 cluster rRNA genes from marine planktonic bacteria. Appl Environ Microbiol 63:63-70

Fuchs BM, Woebken D, Zubkov MV, Burkill P, Amann R (2005) Molecular identification of picoplankton populations in contrasting waters of the Arabian Sea. Aquat Microb Ecol 39:145-157

> Fuhrman JA, Sleeter TD, Carlson CA, Proctor LM (1989) Dominance of bacterial biomass in the Sargasso Sea and its ecological implications. Mar Ecol Prog Ser 57:207-217

Fuhrman JA, Hewson I, Schwalbach MS, Steele JA, Brown MV, Naeem S (2006) Annually reoccurring bacterial communities are predictable from ocean conditions. Proc Natl Acad Sci USA 103:13104-13109

> Garcés E, Vila M, Reñe A, Alonso-Sáez L and others (2007) Natural bacterioplankton assemblage composition during blooms of Alexandrium spp. (Dinophyceae) in NW Mediterranean coastal waters. Aquat Microb Ecol 46: $55-70$

> Garneau ME, Vincent WF, Alonso-Sáez L, Gratton Y, Lovejoy C (2006) Prokaryotic community structure and heterotrophic production in a river-influenced coastal arctic ecosystem. Aquat Microb Ecol 42:27-40

Gasol JM, Duarte CM (2000) Comparative analyses in aquatic microbial ecology: How far do they go? FEMS Microbiol Ecol 31:99-106

> Gasol JM, del Giorgio P, Duarte CM (1997) Biomass distribution in marine planktonic communities. Limnol Oceanogr 42:1353-1363

Gasol JM, Vázquez-Domínguez E, Vaqué D, Agustí S, Duarte CM (2009) Bacterial activity and diffusive nutrient supply in the oligotrophic Central Atlantic Ocean.
Aquat Microb Ecol 56:1-12

> Giovannoni SJ, Stingl U (2005) Molecular diversity and ecology of microbial plankton. Nature 437:343-348

> Glöckner FO, Fuchs BM, Amann R (1999) Bacterioplankton composition of lakes and oceans: a first comparison based on fluorescence in situ hybridization. Appl Environ Microbiol 65:3721-3726

- Gómez-Pereira PR, Fuchs BM, Alonso C, Oliver MJ, van Beusekom JEE, Amann R (2010) Distinct flavobacterial communities in contrasting water masses of the North Atlantic Ocean. ISME J 4:472-487

> Grossart HP, Levold F, Allgaier M, Simon M, Brinkhoff T (2005) Marine diatom species harbor distinct bacterial communities. Environ Microbiol 7:860-873

> Herlemann DP, Labrenz M, Jürgens K, Bertilsson S, Waniek JJ, Andersson AF (2011) Transitions in bacterial communities along the $2000 \mathrm{~km}$ salinity gradient of the Baltic Sea. ISME J 5:1571-1579

> Hold GL, Smith E, Rappé A, Maas MS and others (2001) Characterisation of bacterial communities associated with toxic and non-toxic dinoflagellates: Alexandrium spp. and Scrippsiella trochoidea. FEMS Microbiol Ecol 37:161-173

Karner M, Fuhrman JA (1997) Determination of active marine bacterioplankton: a comparison of universal 16S rRNA probes, autoradiography, and nucleoid staining. Appl Environ Microbiol 63:1208-1213

Kirchman DL, Castle D (2004) Composition of estuarine bacterial communities assessed by denaturing gradient gel electrophoresis and fluorescence in situ hybridization. Limnol Oceanogr Methods 2:303-314

> Kirchman DL, Yu LY, Cottrell MT (2003) Diversity and abundance of uncultured Cytophaga-like bacteria in the Delaware Estuary. Appl Environ Microbiol 69:6587-6596

> Kirchman DL, Dittel AI, Malmstrom RR, Cottrell MT (2005) Biogeography of major bacterial groups in the Delaware Estuary. Limnol Oceanogr 50:1697-1706

Legendre P, Legendre L (1998) Numerical ecology. Developments in environmental modeling, 2nd edn. Elsevier, Amsterdam

Li WKW, Dickie PM, Harrison WG, Irwin BD (1993) Biomass and production of bacteria and phytoplankton during the spring bloom in the western North Atlantic Ocean. DeepSea Res 40:307-327

Li WKW, Head JH, Harrison WG (2004) Macroecological limits of heterotrophic bacterial abundance in the ocean. Deep-Sea Res I 51:1529-1540

> Lin X, Wakeham SG, Putnam IF, Astor YM, Scranton MI, Chistoserdov AY, Taylor GT (2006) Comparison of vertical distributions of prokaryotic assemblages in the anoxic Cariaco Basin and Black Sea by use of fluorescence in situ hybridization. Appl Environ Microbiol 72:2679-2690

> Lin X, Scranton MI, Varela R, Chistoserdov A, Taylor GT (2007) Compositional responses of bacterial communities to redox gradients and grazing in the anoxic Cariaco Basin. Aquat Microb Ecol 47:57-72

Lin X, Scranton MI, Chistoserdov AY, Varela R, Taylor GT (2008) Spatio-temporal dynamics of bacterial populations in the anoxic Cariaco Basin. Limnol Oceanogr 53:37-51

> Llobet-Brossa E, Rosselló-Mora R, Amann R (1998) Microbial community composition of Wadden Sea sediments as revealed by fluorescence in situ hybridization. Appl Environ Microbiol 64:2691-2696

Longnecker K, Homen DS, Sherr EB, Sherr BF (2006) Similar community structure of biosynthetically active prokary- 
otes across a range of ecosystem trophic states. Aquat Microb Ecol 42:265-276

Manz W, Amann R, Ludwig W, Wagner M, Schleifer KH (1992) Phylogenetic oligonucleotide probes for the major subclasses of Proteobacteria: problems and solutions. Syst Appl Microbiol 15:593-600

Manz W, Amann R, Ludwig W, Vancanneyt M, Schleifer KH (1996) Application of a suite of 16S rRNA-specific oligonucleotide probes designed to investigate bacteria of the phylum Cytophaga-Flavobacter-Bacteroides in the natural environment. Microbiology 142:1097-1106

Mary I, Cummings DG, Biegala IC, Burkill PH, Archer SD, Zubkov MV (2006) Seasonal dynamics of bacterioplankton community structure at a coastal station in the western English Channel. Aquat Microb Ecol 42:119-126

Morán XAG, Estrada M, Gasol JM, Pedrós-Alió C (2002) Dissolved primary production and the strength of phytoplankton-bacterioplankton coupling in contrasting marine regions. Microb Ecol 44:217-223

> Morris RM, Rappé MS, Connon SA, Vergin KL, Siebold WA, Carlson CA, Giovannoni SJ (2002) SAR11 clade dominates ocean surface bacterioplankton communities. Nature 420:806-810

Morris RM, Vergin KL, Cho JC, Rappé MS, Carlson CA, Giovannoni SJ (2005) Temporal and spatial response of bacterioplankton lineages to annual convective overturn at the Bermuda Atlantic Time-series study site. Limnol Oceanogr 50:1687-1696

Murray AE, Preston CM, Massana R, Taylor LT, Blakis A, Wu K, Delong EF (1998) Seasonal and spatial variability of bacterial and archaeal assemblages in the coastal waters near Anvers Island, Antarctica. Appl Environ Microbiol 64:2585-2595

Nagata T (2000) Production mechanisms of dissolved organic matter. In: Kirchman DL (ed) Microbial ecology of the oceans. John Wiley \& Sons, New York, NY, p 121-152

> O'Sullivan LA, Fuller KE, Thomas EM, Turley CM, Fry JC, Weightman AJ (2004) Distribution and culturability of the uncultivated 'AGG58 cluster' of the Bacteroidetes phylum in aquatic environments. FEMS Microbiol Ecol 47:359-370

> Obernosterer I, Catala P, Lami R, Caparros J and others (2008) Biochemical characteristics and bacterial community structure of the sea surface microlayer in the South Pacific Ocean. Biogeosciences 5:693-705

> Oda Y, Slagman SJ, Meijer WG, Forney LJ, Gottschall JC (2000) Influence of growth rate and starvation on fluorescent in situ hybridization of Rhodopseudomonas palustris. FEMS Microbiol Ecol 32:205-213

> Pace ML, Cole JJ (1994) Comparative and experimental approaches to top-down and bottom-up regulation of bacteria. Microb Ecol 28:181-193

Pernthaler A, Preston CM, Pernthaler J, Delong EF, Amann R (2002) Comparison of fluorescently labeled oligonucleotide and polynucleotide probes for the detection of pelagic marine bacteria and archaea. Appl Environ Microbiol 68:661-667

Pernthaler A, Pernthaler J, Amann R (2004) Sensitive multicolor fluorescence in situ hybridization for the identification of environmental microorganisms. In: Akkermans ADL, de Bruijn FJ, van Elsas JD (eds) Molecular microbial ecology manual, 2nd edn. Kluwer Academic Publishers, Dordrecht, p 711-726

- Piccini C, Conde D, Alonso C, Sommaruga R, Pernthaler J
(2006) Blooms of single bacterial species in a coastal lagoon of the southwestern Atlantic Ocean. Appl Environ Microbiol 72:6560-6568

Pinhassi J, Sala MM, Havskum H, Peters F, Guadayol O, Malits A, Marrasé C (2004) Changes in bacterioplankton composition under different phytoplankton regimens. Appl Environ Microbiol 70:6753-6766

Pommier T, Canbäck B, Riemann L, Boström KH and others (2007) Global patterns of diversity and community structure in marine bacterioplankton. Mol Ecol 16:867-880

Riemann L, Steward GF, Azam F (2000) Dynamics of bacterial community composition and activity during a mesocosm diatom bloom. Appl Environ Microbiol 66:578-587

Rooney-Varga JN, Giewat MW, Savin MC, Sood S, LeGresley M, Martin JL (2005) Links between phytoplankton and bacterial community dynamics in a coastal marine environment. Microb Ecol 49:163-175

> Sapp M, Wichels A, Wiltshire KH, Gerdts G (2007) Bacterial community dynamics during the winter-spring transition in the North Sea. FEMS Microbiol Ecol 59:622-637

Sarmento H, Gasol JM (2012) Use of phytoplankton-derived dissolved organic carbon by different types of bacterioplankton. Environ Microbiol 14:2348-2360

Schattenhofer M, Fuchs BM, Amann R, Zubkov MV, Tarran GA, Pernthaler J (2009) Latitudinal distribution of prokaryotic picoplankton populations in the Atlantic Ocean. Environ Microbiol 11:2078-2093

> Schönhuber W, Fuchs B, Juretschko S, Amann R (1997) Improved sensitivity of whole-cell hybridization by the combination of horseradish peroxidase-labeled oligonucleotides and tyramide signal amplification. Appl Environ Microbiol 63:3268-3273

> Selje N, Simon M, Brinkhoff T (2004) A newly discovered Roseobacter cluster in temperate and polar oceans. Nature 427:445-448

> Simon M, Cho BC, Azam F (1992) Significance of bacterial biomass in lakes and the ocean: comparison to phytoplankton biomass and biogeochemical implications. Mar Ecol Prog Ser 86:103-110

Simon M, Glöckner FO, Amann R (1999) Different community structure and temperature optima of heterotrophic picoplankton in various regions of the Southern Ocean. Aquat Microb Ecol 18:275-284

Somarakis S, Ganias K, Siapatis A, Koutsikopoulos C, Machias A, Papaconstantinou C (2006) Spawning habitat and daily egg production of sardine (Sardina pilchardus) in the eastern Mediterranean. Fish Oceanogr 15:281-292

- Stoica E, Herndl GJ (2007) Bacterioplankton community composition in nearshore waters of the NW Black Sea during consecutive diatom and coccolithophorid blooms. Aquat Sci 69:413-418

Tada Y, Tanigushi A, Nagao I, Miki T, Uematsu M, Tsuda A, Hamasaki K (2011) Differing growth responses of major phylogenetic groups of marine bacteria to natural phytoplankton blooms in the western north Pacific Ocean. Appl Environ Microbiol 77:4055-4065

- Teira E, Gasol JM, Aranguren-Gassis M, Fernández A, González J, Lekunberri I, Álvarez-Salgado XA (2008) Linkages between bacterioplankton community composition, heterotrophic carbon cycling and environmental conditions in a highly dynamic coastal ecosystem. Environ Microbiol 10:906-917

Tolker-Nielsen T, Larsen MH, Kyed H, Molin S (1997) Effects of stress treatments on the detection of Salmonella typhimurium by in situ hybridization. Int J Food 
Microbiol 35:251-258

Topping JN, Heywood JL, Ward P, Zubkov MV (2006) Bacterioplankton composition in the Scotia Sea, Antarctica, during the austral summer of 2003. Aquat Microb Ecol 45:229-235

van Hannen EJ, Zwart G, van Agterveld MP, Gons HJ, Ebert J, Laanbroek HJ (1999) Changes in bacterial and eukaryotic community structure after mass lysis of filamentous cyanobacteria associated with viruses. Appl Environ Microbiol 65:795-801

Vila M, Simó R, Kiene RP, Pinhassi J, González JM, Moran MA, Pedrós-Alió C (2004) Use of microautoradiography combined with fluorescence in situ hybridization to determine dimethylsulfoniopropionate incorporation by marine bacterioplankton taxa. Appl Environ Microbiol 70:4648-4657

von Wintzingerode F, Göbel UB, Stackebrandt E (1997) Determination of microbial diversity in environmental samples: pitfalls of PCR-based rRNA analysis. FEMS Microbiol Rev 21:213-229

Wallner G, Amann R, Beisker W (1993) Optimizing fluorescent in situ hybridization with rRNA-targeted oligonucleotide probes for flow cytometric identification of microorganisms. Cytometry 14:136-143

Wells LE, Deming JW (2003) Abundance of Bacteria, the Cytophaga-Flavobacterium cluster and Archaea in cold oligotrophic waters and nepheloid layers of the Northwest Passage, Canadian Archipelago. Aquat Microb Ecol $31: 19-31$
Wietz M, Gram L, Jørgensen B, Schramm A (2010) Latitudinal patterns in the abundance of major marine bacterioplankton groups. Aquat Microb Ecol 61:179-189

Yoder JA, Doney SC, Siegel DA, Wilson C (2010) Study of marine ecosystems and biogeochemistry now and in the future: examples of the unique contributions from space. Oceanography 23:104-117

Yokokawa T, Nagata T (2005) Growth and grazing mortality rates of phylogenetic groups of bacterioplankton in coastal marine environments. Appl Environ Microbiol 71:6799-6807

Yokokawa T, Nagata T, Cottrell MT, Kirchman DL (2004) Growth rate of the major phylogenetic bacterial groups in the Delaware estuary. Limnol Oceanogr 49:1620-1629

Zar JH (1999) Biostatistical analysis, 4th edn. Prentice Hall, NJ

Zhang Y, Jiao N, Cottrell MT, Kirchman DL (2006) Contribution of major bacterial groups to bacterial biomass production along a salinity gradient in the South China Sea. Aquat Microb Ecol 43:233-241

Zubkov MV, Fuchs BM, Archer SD, Kiene RP, Amann R, Burkill PH (2001) Linking the composition of bacterioplankton to rapid turnover of dissolved dimethylsulphoniopropionate in an algal bloom in the North Sea. Environ Microbiol 3:304-311

Zubkov MV, Fuchs BM, Tarran GA, Burkill PH, Amann R (2002) Mesoscale distribution of dominant bacterioplankton groups in the northern North Sea in early summer. Aquat Microb Ecol 29:135-144

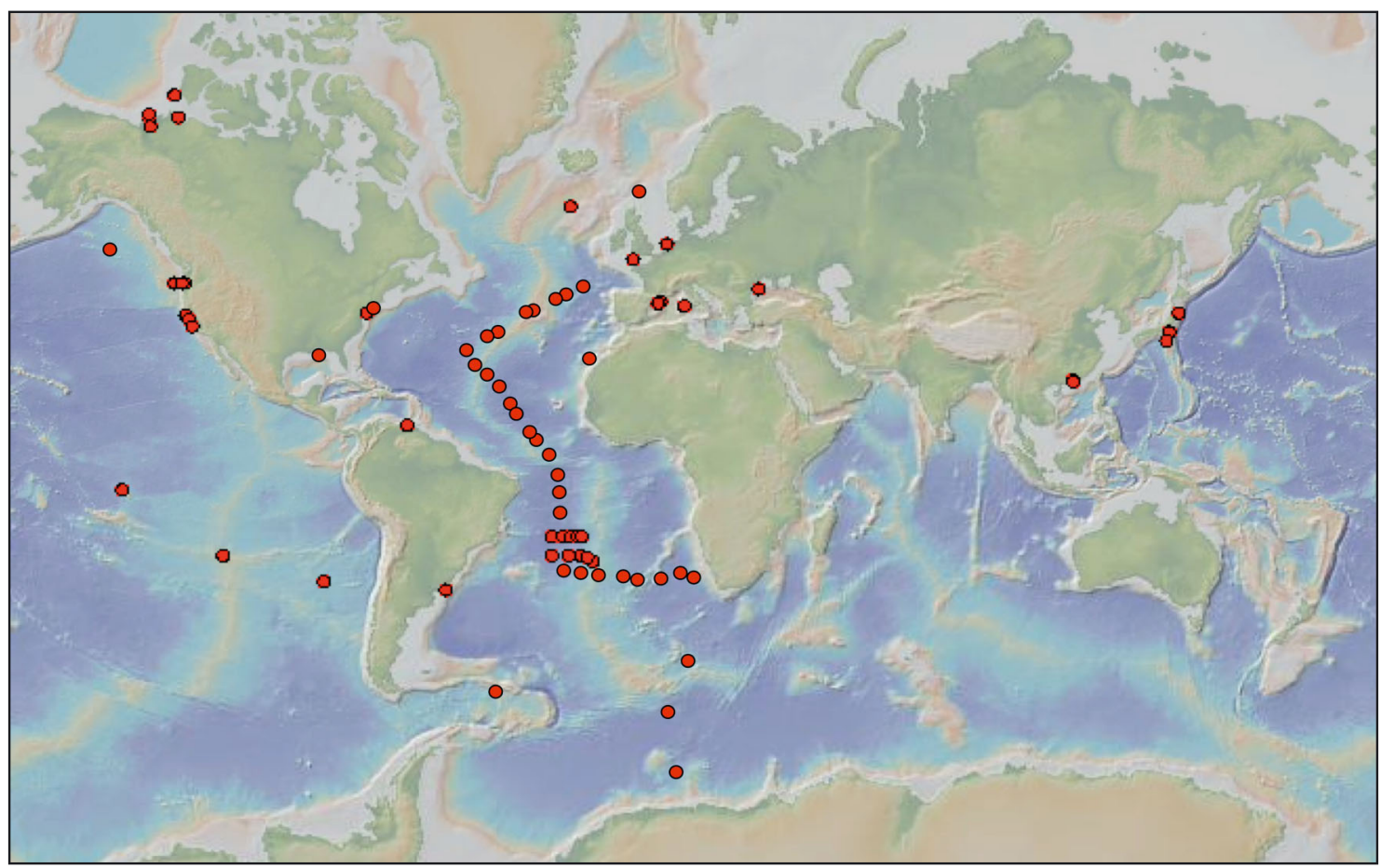

Appendix 1. Sampling sites used in the studies selected for this meta-analysis (compiled in Table 1)

Editorial responsibility: Hans-Georg Hoppe, Kiel, Germany
Submitted: October 1, 2012; Accepted: May 25, 2013

Proofs received from author(s): August 14, 2013 